\title{
The role of business models in firm internationalization: An exploration of European electricity firms in the context of the energy transition
}

\author{
René Bohnsack ${ }^{1}$, \\ Francesca Ciulli ${ }^{2}$ and Ans Kolk ${ }^{3}$ \\ ${ }^{1}$ Católica Lisbon School of Business \& Economics, \\ Lisbon, Portugal; ${ }^{2}$ Institute for Management \\ Research, Radboud University Nijmegen, \\ Nijmegen, The Netherlands; ${ }^{3}$ Amsterdam Business \\ School, University of Amsterdam, Amsterdam, The \\ Netherlands
}

Correspondence:

A Kolk, Amsterdam Business School, University of Amsterdam, Amsterdam, The Netherlands

e-mail: akolk@uva.nl

\begin{abstract}
This article ties in directly with recently intensified interest in business models in international business (IB), using the energy transition as empirical context to explore their relevance in firm internationalization. The global energy transition presents a challenge for almost all industries, but some face specific difficulties particularly important from an IB perspective. We study a set of European firms that used to operate in a highly regulated context with (partial) state ownership, until government-directed market liberalization started to allow further competition and internationalization. Existing firms were prompted to adapt their business models to these changes, with new ventures entering the market to reap opportunities with novel energy-related technologies and business models. Linking insights from strategic management to the IB literature, we conceptualize business model-related specific advantages (BMSAs), and explore the role of BMSAs in the internationalization of the firms in our sample. We also uncover barriers to BMSA recombination in (potential) host countries, consider BMSA location-boundedness, and discuss implications for firms' international expansion by presenting a new framework. Consequences for the energy transition and the actors already involved and (in)directly confronted with it are explicated, while outlining promising areas for further research, building on the insights and limitations of our study.

Journal of International Business Studies (2021) 52, 824-852. https://doi.org/ | 0. 1057/s4 | 267-020-00364-4
\end{abstract}

Keywords: internationalization; firm-specific advantages; location-bound/non-locationbound; business model; energy; internalization theory

The online version of this article is available Open Access

\section{INTRODUCTION}

The global energy transition presents a challenge for almost all industries, but some face specific difficulties. Highly relevant from both an international business (IB) and an energy transition perspective are firms in the electricity sector. These firms operate in a context in which regulation and (partial) state ownership used
Received: 1 February 2019

Revised: 6 August 2020

Accepted: 13 August 2020

Online publication date: 14 October 2020 
to prevail until policy changes started to drive the opening of markets and increasing cross-border competition (Kolk, Lindeque, \& Van den Buuse, 2014). At the same time, electricity firms have dealt with novel technologies that rely particularly on renewable energy sources, energy efficiency, and the more active involvement of a range of actors, including customers, which require novel business models (Hancher \& Winters, 2017). In this vein, the 2018 World Energy Outlook of the International Energy Agency focused specifically on electricity, noted to be "at the forefront of the clean-energy transitions", with the sector being described by its Executive Director as "witnessing its most dramatic transformation since its birth more than a century ago" (IEA, 2018). Seen from an IB perspective, the current stage of the energy transition is characterized by an uneven degree of internationalization among electricity firms, with 'traditional' business models co-existing with and being challenged by novel ones relying on new technologies, against the background of liberalization policies coupled with persisting national approaches (Geels et al., 2016).

The international expansion of firms in the electricity sector represents a promising phenomenon for advancing internationalization theory through a business model perspective. Indeed, it is characterized by established firms and new entrants with a variety of business models, which have to take their internationalization decisions in a context of increasingly, albeit heterogeneous, open markets, and rising, though fragmented, diffusion of novel technologies (Dahlmann, Kolk, \& Lindeque, 2017). In line with the phenomenonbased research approach described by Doh (2015, p. 609), we conceptualized this "contemporary, real-world" phenomenon by "identif[ying] a theory or set of theories that can inform [this] reality" (cf. Buckley, Doh, \& Benischke, 2017), and then proceeded with theorizing to advance IB research. We posit that the assessment of firm-specific advantages (FSAs) inherent to a firm's business model, and their location-boundedness, are critical for internationalization decisions. The business model has been mentioned in previous IB literature as key for realizing a competitive advantage across borders (e.g., Rugman \& Verbeke, 2004). In fact, Verbeke, Coeurderoy and Matt (2018) recently indicated that FSAs may also come in the form of business models. However, thus far, the role and potential of the business model concept in relation to FSAs and firm internationalization have not been studied in detail (cf. Tallman, Luo, \& Buckley, 2018), let alone in the context of a grand challenge such as the energy transition.

A business model lens allows us to complement the existing resource-based interpretation of FSAs in IB (Narula, Asmussen, Chi, \& Kundu, 2019; Rugman \& Verbeke, 2003; Verbeke \& Asmussen, 2016), given that business models represent configurations of "resources in use" (Demil, Lecocq, Ricart, \& Zott, 2015, pp. 2-3). What we conceptualize in this paper as business model-related specific advantage (BMSA) is tied to the configuration of value creation and capture components from a boundary-spanning, systemic perspective proposed by strategic management research (Massa, Tucci, \& Afuah, 2017; Zott \& Amit, 2010). We posit that the degree to which the individual components of the business model are location-bound or non-location bound - i.e., linked to local idiosyncrasies, local knowledge, or local innovation activities - renders the entire BMSA configuration on a continuum either as (more) location-bound or as (more) nonlocation bound. In addition, we propose that firms need to 'recombine' (Grøgaard, Colman, \& Stensaker, 2019) their home country BMSA in host countries in order to thrive internationally. The barriers to recombination faced by a firm (e.g., related to regulation, infrastructure, or the market) can also be on a continuum from higher to lower. We suggest that the combination of BMSA and recombination barriers influences the internationalization of firms. Thus, to improve our understanding of whether and how firms enter foreign markets, it is important to assess (1) whether a firm's BMSA is non-location or location-bound, and (2) whether the recombination barriers in a (potential) host country are high or low. ${ }^{1}$

Relating IB to business model research, as explicated further in the next section, this article thus aims to shed light on the role that BMSAs play in the internationalization of firms. We subsequently explore this empirically in the context of the energy transition, with a specific focus on 14 firms covering all the core types of activities in the European electricity sector. These firms are analyzed through an explorative qualitative research design, relying on interviews to uncover BMSAs, their location-boundedness across the components of the firms' business model configuration, barriers to BMSA recombination in (potential) host countries, and implications for their international expansion. In doing so, we make several contributions to IB research. First, by proposing the BMSA 
construct as a new kind of FSA, we are able to bring rich insights from strategic management research on business models, where this concept is more established, into the IB field to develop earlier concise yet highly relevant references to the business model as an FSA (e.g., Hennart, 2009; Verbeke et al., 2018). In this way, the article also responds to recent calls for more research on business models, expressed inter alia at the Academy of International Business 2020 virtual conference. In addition, our work uncovers the existence of barriers in the host country hindering BMSA recombination, thus also enriching that literature. We furthermore present the implications of BMSA location-boundedness and BMSA host-country recombination barriers for a firm's international expansion through a new framework. Our final section discusses implications for IB scholars as well as for those involved in multinationals' strategy and policymaking.

\section{THEORETICAL BACKGROUND}

\section{Location-Bound and Non-location-Bound FSAs}

Stemming from a resource-based view of internalization theory, the "Rugman school" (Narula et al., 2019) posits that successful international expansion depends on firm-specific advantages, i.e., the "firm's unique knowledge resource-bundles in which it had invested as the foundation of survival, value creation and growth" (Verbeke \& Kano, 2016, p. 84). Rugman and Verbeke (2001, 2003, 2004) have distinguished non-location-bound FSAs and location-bound FSAs. Non-location-bound FSAs such as final products, intermediate products or key routines - create value in multiple markets, and can thus be easily transferred and profitably exploited across countries (Rugman \& Verbeke, 2001; Verbeke, 2009), enabling a rapid and efficient international expansion (Grøgaard et al., 2019). By being deployed in multiple markets, non-location-bound FSAs allow the firm to benefit from economies of scale and scope (Rugman \& Verbeke, 2001). Location-bound FSAs - such as local knowledge, local reputation or local best-practices - "benefit the company only in a particular location" (Rugman \& Verbeke, 2001, p. 241). The value of a firm's FSAs may thus be limited to a country or region and cannot be capitalized in other markets (Grøgaard et al., 2019). Location-bound and non-locationbound FSAs are often developed from the inception of the firm, imprinted by founders, and are continuously shaped by external circumstances. The FSA portfolio of a multinational enterprise (MNE) can include both location- and non-location-bound FSAs. Not least, this diverse "geographic 'reach' or fungibility of FSAs" (Narula et al., 2019, p. 1233) reflects the pressures for global integration and local responsiveness that MNEs experience with different degrees of intensity (Grøgaard et al., 2019).

In keeping with the compound nature of a firm's FSAs, the concept of "FSA recombination" has been brought forward by the new internalization theory (e.g., Grøgaard et al., 2019), reflecting growing attention among IB scholars. FSA recombination indicates the need for an MNE to enhance the value of its non-location-bound FSAs by combining and "melding" (Pitelis \& Verbeke, 2007) them with location-specific assets in foreign markets (Coviello, Kano, \& Liesch, 2017). The ability to bundle FSAs with location-specific assets in the host country requires entrepreneurial capabilities as well as slack resources. It has been defined as a highest-order FSA and the "raison d'être of an MNE" (Narula, 2014, p. 10). While an MNE can sometimes be internationally competitive by 'simply' transferring and exploiting its non-location-bound FSAs (Verbeke \& Kano, 2016), they are important but not sufficient for a successful foreign expansion to a host country in many other cases, in which access to complementary local assets is paramount (Narula et al., 2019).

Hence, to be able to compete in a host country, a firm with non-location-bound FSAs may still need to acquire new location-bound strengths that fulfill local needs and requirements (Grøgaard et al., 2019; Rugman \& Verbeke, 2001). Securing these local resources may be critical for a firm to gain access to the country-specific advantages (CSAs) of the foreign market and thus ensure competitiveness. For example, being connected to a local distribution network is key to reaching an attractive customer segment in the targeted host country (Rugman, Verbeke, \& Nguyen, 2011). By effectively bundling non-location-bound FSAs with host country-specific assets, a firm can create new locationbound FSAs (Grøgaard et al., 2019; Narula \& Verbeke, 2015; Rugman et al., 2011; Verbeke, 2009). FSA recombination may be realized by directly obtaining the assets needed or by acquiring or partnering with local actors that own or control such assets (Hennart, 2009; Narula et al., 2019; Rugman et al., 2011; Verbeke \& Kano, 2016).

Having said that, it should be noted that the firms included in this body of work are typically 
large (MNEs), rather than existing smaller ones (SMEs) that are (about to start) internationalizing. While SMEs face specific challenges and additional liabilities in internationalization - largely due to limited resources and market knowledge (e.g., Hollender, Zapkau, \& Schwens, 2017; Knight \& Liesch, 2016; Lu \& Beamish, 2001; Pisani, Caldart, \& Hopma, 2017), compared to (large) MNEs - some of the conceptualizations and findings may also apply to smaller firms, especially in the empirical setting of this study. Earlier research has, inter alia, shown that SMEs, like MNEs, benefit from experiential knowledge, i.e., FSAs (Love, Roper, \& Zhou, 2016), and they have also been found to benefit from CSAs (Ciravegna, Lopez, \& Kundu, 2014; Lee \& Marvel, 2009). Moreover, incremental, initially smaller-scale, expansion to neighboring countries that are relatively familiar in cultural and economic terms is easier to achieve for SMEs (e.g., Laufs \& Schwens, 2014; Lee \& Marvel, 2009); the activities undertaken in the electricity sector, within the EU policy framework, fit these criteria.

\section{Linking FSAs to Business Models}

In line with the resource-based view (RBV) of the firm, FSAs have traditionally been conceptualized as proprietary assets and resource characteristics that a firm needs to own in order to have a competitive advantage over other firms and thus "engage in foreign activities" (Narula et al., 2019, p. 1234). Interestingly, several prominent IB scholars have hinted at FSAs as also encompassing the whole business model of a firm. More specifically, Rugman and Verbeke (2004, p. 10) had, early on, already indicated that MNEs such as Nike and Walmart could "outperform[... other competitors" precisely because of their specific business model. Verbeke et al. (2018) mentioned business models in their listing of non-location-bound FSAs, while also noting a scarcity of insight into these components in IB research. Furthermore, when arguing that "knowledge is the main FSA that MNEs seek to exploit in foreign markets", Hennart (2009, p. 1437) demonstrated the use of a very broad definition of knowledge that includes "the business models".

Despite these more generic references, attention to business models in the IB literature has been scarce. To the authors' knowledge, only Tallman et al. (2018) have made a first conceptual attempt to connect the IB literature to (non-IB) business model research. Their reflections on the relationship between FSAs and business models are, however, limited and different from the authors mentioned earlier in this paragraph. Tallman et al. (2018, p. 529) seem to conceptualize FSAs and business models as two separate constructs, arguing that FSAs "should be coupled with a business model". Furthermore, there are two initial empirical studies, both exploratory cases, on a business model in relation to international expansion: Cavallo, Ghezzi and Guzmán (2019) on a Columbian agritech company, and Dunford, Palmer and Benveniste (2010) on ING Direct. Both articles, however, take the perspective of an individual firm with a business model that needs to change/evolve during an internationalization process, without considering the variety in firms' business models and related advantages. In addition, they display a limited integration of IB and business model literature, thus not fully exploiting its potential. Although still not reflected in publications, the business model concept has recently gained increasingly attention in IB scholars' debates, epitomized by sessions on the business model as a missing link in internationalization theory, and on how the business model concept can contribute to international business, held at the Academy of International Business 2020 virtual conference.

In this paper, we build on the perspectives taken by Hennart, Rugman, and Verbeke et al. with the aim of shedding more light on the FSA-business model relationship, while also leveraging the strategic management literature, where the business model concept has been more extensively investigated. This body of work has most often defined the business model concept as "the rationale of how an organization creates, delivers and captures value" (Osterwalder \& Pigneur, 2010, p. 14). It describes the business model as a firm's underlying dominant logic and strategic choice, and hence an architecture framework to earn profit (Casadesus-Masanell \& Ricart, 2010; Magretta, 2002; Morris, Schindehutte \& Allen, 2005; Prahalad \& Bettis, 1986; Teece, 2010). Scholars who have confronted the work on business models and the RBV (e.g., Demil et al., 2015; Teece, 2018), have pointed at their complementarity. According to Demil et al. (2015, p. 3), for example, the business model perspective is in line with a 'traditional' resource-based view of competitive advantage, because "the business model emphasizes configurations of resources in use (Penrose, 1959)" [emphasis in original].

In linking business models to FSAs, we follow existing frameworks (Chesbrough \& Rosenbloom, 
2002; Demil \& Lecocq, 2010; Morris et al., 2005; Osterwalder \& Pigneur, 2010) and distinguish three business model components: the value proposition, the value network, and the revenue-cost model (Bohnsack, Pinkse \& Kolk, 2014). The value proposition is a core component of each business model and describes the value created for the customer; it connects the firms' activities with the demand side. The value network describes the company's approach to value creation and position with regard to its relationships with external actors, including, in particular, suppliers, distributors, customers, and competitors. The revenue-cost model involves the cost structure and monetization mode of the firm's offerings (Baden-Fuller \& Haefliger, 2013; Chesbrough \& Rosenbloom, 2002). The smart configuration of the three components enables a firm to create more value and gain an advantage over competitors (Casadesus-Masanell \& Ricart, 2010).

\section{On Business Model-Related Specific Advantages (BMSAs)}

When linked to FSAs, the business model concept adds two core features: the higher-order configurational character and the link to external actors. First, BMSAs seem particularly pertinent when examining firms aiming to internationalize during technology-intensive changes, of which the energy transition is an example, given that the shift from fossil-fuel-based electricity generation to renewables depends on new technologies for the production, distribution, and consumption of electricity. While extant IB literature has indicated technology as a core FSA (e.g., Grøgaard et al., 2019), Massa et al. (2017, p. 91) state that "innovative technologies and ideas, per se, have no economic value, but only latent value. It is the function of the business model to realize part of that value by connecting these technologies and ideas to the realization of economic output in markets". An MNE thus needs to combine a new technology with a suitable business model, that is, to set up a configuration of activities that create and capture value and that allow the MNE to deploy and successfully exploit the technology across borders. Each activity of the configuration can be attributed to a component of the business model and, in doing so, allows us to identify which specific business model component(s) - within the whole rationale of how the firm creates, delivers, and captures value - are nonlocation bound and can be transferred internationally, and which one(s) are location-bound and might need modification in host countries in order for the firm to be competitive.

With regard to the latter, the value of a business model perspective to FSAs is also tied to the integration of actors external to the focal firm that critically contribute to its international competitiveness. Value co-creation with an array of external actors within and across countries has become increasingly important for internationalizing firms, also thanks to novel technologies (Coviello et al., 2017). This is acknowledged in recent internationalization literature which, according to Hennart (2009), has gradually shifted from being "MNEcentric" towards increasing attention to ecosystems and networks (e.g., Coviello et al., 2017; Narula \& Verbeke, 2015; Vahlne \& Johanson, 2017). Networked value creation and capture is also often at the basis of FSA recombination, which entails the collaboration with external partners that own or control key location-specific assets (Narula \& Verbeke, 2015; Verbeke \& Kano, 2016). The business model concept, with its "integrated, holistic and balanced consideration of value creation and capture" (Demil et al., 2015, p. 5), which encompasses the focal firm and its network of suppliers, customers, and partners (Zott \& Amit, 2010), allows us to apprehend the increasingly central role played by external actors in a firm's international expansion.

As the business model perspective enables an extension of the concept of FSAs to include the whole configuration of value creation and capture, as designed by the focal firm and its stakeholders across countries, we use the concept of a BMSA (as already mentioned in the "Introduction") to indicate a configuration of location-bound and nonlocation-bound activities that, as a whole, lead to a firm-specific advantage. For some firms, the BMSA configuration may be transferred and leveraged internationally with no or just minor adaptations if all the three business model components are nonlocation-bound. The BMSA of other firms may instead result in competitiveness only in the home country, but not internationally. In that case, in order to then ensure value creation and capture in foreign markets, the business model requires adaptation, through recombination with location-specific assets. Figure 1 presents a framework that depicts the location-specificity of a BMSA by combining, on the vertical axis, the business model components (value proposition, value network, and the revenue-cost model) with, on the horizontal axis, the location-boundedness of the BMSA 


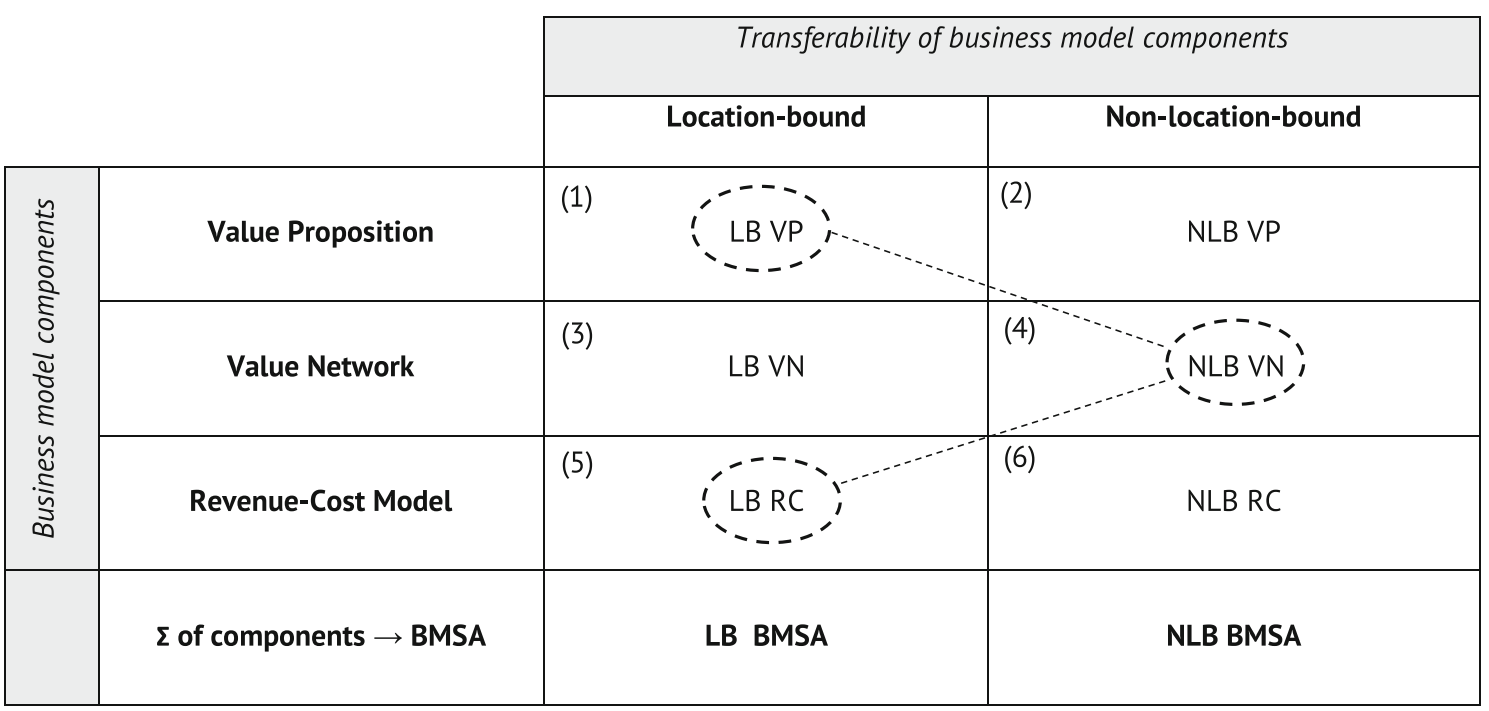

Figure 1 Conceptual framework for BMSA location-boundedness (the exemplary configuration represented by the dashed lines illustrates the underlying logic; numbers in the cells are included as guidance to relate to cases in the findings).

components. This framework thus allows for a reflection on the extent to which a firm's BMSA is transferable. A BMSA is highly transferable if all elements of the business models are non-locationbound, but more difficult to transfer the more elements of the business model are location-bound. This framework helps to identify the overall configuration of the business model as well as the components that a firm needs to adapt or recreate in a host market to be able to still rely on the BMSA. We will use it as guidance for our empirical exploration in this paper.

\section{RESEARCH DESIGN}

In order to shed light on the role of the BMSA in firms' internationalization, we applied an exploratory qualitative approach based on a multiple-case study design (Eisenhardt, 1989; Yin, 1994). We considered this appropriate given the novelty of the topic under investigation, and the adoption of a phenomenon-based research approach. More details will be given below on the empirical context and sample as well as the data collection and analysis.

\section{Empirical Context}

The energy transition affects organizations and institutions across industries and regions. A case in point is the electricity industry in the European Union (EU) which has witnessed fundamental changes in the past decade, triggered by the increasing share of renewable energy sources (e.g., wind and solar energy), policymaking to liberalize energy markets, and, most recently, the digitalization wave. First, while traditionally electricity was "generated in large power plants operating in a central location" (Alanne \& Saari, 2006, p. 541), and essentially included coal, gas, and nuclear power stations, the growth of electricity generation from renewables has led to a more variable and decentralized electricity system, with "households, community groups, new energy companies, as well as utilities with new business models all becoming producer-consumer" (Smith \& Raven, 2012, p. 1033).

Second, the EU institutions have been promoting a European single market since 1996, reconfiguring the industry context in which firms operate by implementing pro-market reforms. In particular, the Third Energy Package - enacted in 2009, and consisting of three regulations and directives - was a milestone in EU energy market legislation, as it opened up business opportunities for new players in the industry, and paved the way for more crossborder business transactions. Before 2009, the energy markets in the EU member states were marked by isolated, monopolistic systems, in which dominant market players controlled vertically integrated value chains ${ }^{2}$ reliant on a few, specific energy sources. With the goal of providing secure, competitive, and sustainable energy supply, next to driving the European integration overall and the creation of a single electricity market, the Third Energy package liberalized the gas and electricity 
industry, by directing the 'unbundling', i.e., "the separation of energy supply and generation from the operation of transmission networks" (European Commission, 2019). As a result of these measures, "the [EU] electricity industry has been transformed" (Pollitt, 2019, p. 82), with an increase in competition, the rise in access to diverse sources of energy in each national market, and the intensification of electricity trade between EU countries, which increased by $25 \%$ between 2010 and 2018 (ENTSO-E, 2010, 2019).

Third, the emergence of new technologies has helped to match demand and supply in a system increasingly reliant on renewable energy installations, which are intermittent because electricity generation depends on time and weather conditions, such as in the case of wind and solar power (Alotto, Guarnieri \& Moro, 2014; Müller \& Möst, 2018). The development of technologies such as energy storage and demand response applications have been promising in tackling this issue by enabling control of the demand side by, for example, automatically turning on and off machines in production plants or appliances in private households to better match the constantly changing supply of electricity (Feuerriegel \& Neumann, 2016). In particular, digital technologies in the form of mobile phone applications or smart sensors at home, such as Google's smart home system, Nest, have enabled companies to engage directly with customers, for example, with respect to sharing data about electricity consumption and incentivizing electricity-saving behavior.

The major changes illustrated above have resulted in the burgeoning of different, usually smaller, firms along the electricity value chain that challenge the incumbents' established positions through new business models. The current stage in the energy transition is thus characterized by the coexistence of traditional and novel business models. These transformations have also unlocked opportunities for internationalization; ideally, increasing internationalization would lead to faster dissemination of technologies and accelerate the energy transition. Yet, thus far, few companies in the electricity sector have been able to seize international opportunities, and difficulties seem to be present. This richness of business models and the different patterns of international expansion characterizing the electricity sector provide a particularly relevant context to shed light on the role of BMSA for firms' internationalization.

\section{Sample}

In line with the key characteristics of the empirical setting outlined, we ventured to select firms for our study that covered the whole electricity sector. This entailed moving beyond the utilities that have been studied most often, and also including smaller firms engaging in core activities that characterize the sector as it has evolved due to liberalization and technological transformation. The types of activities we aimed to capture include: electricity production, transmission, distribution, supply, and technology provision. However, finding firms that were not only willing to be interviewed but also to disclose their business models, internationalization strategies, and experiences thus far, proved rather difficult. This stems from the difficulties they face in making time available to expose the complexities of their specific activities, coupled with competitive concerns in an industry in a state of transition.

We therefore decided to approach the firms that participated in a large-scale, four-year European Innovation project, i.e., the H2020 project inteGRIDy, which had as its aim to integrate novel technologies into smart electricity grids. This made it easier to gain access to firms open to being interviewed and sharing information, as there was already some familiarity with their foci and scopes. ${ }^{3}$ Each company partner was contacted through the respective project manager. In addition, where possible, further representatives who could give information on the internationalization processes were solicited via the project manager. Our convenience sampling approach allowed us to compile a list of firms that (1) covered all the core types of activities in the electricity sector, (2) included both incumbents and new entrants in the industry, (3) helped to understand mechanisms across actors, and (4) provided a suitable context to talk openly about strategic ambitions.

In the end, we were able to secure participation from 14 companies (see Table 1 for relevant details for each of them) exhibiting the variation inherent to the sector in this time and age. Since the goal of this study is to shed light on a relatively novel and 'real-world' phenomenon as it unfolds, a convenience sample is appropriate (cf. Knight, Holdsworth, \& Mather, 2007; Phene \& Almeida, 2008; Pornpitakpan, 1999).

\section{Data Collection}

Since the nature of the insights we aimed to gain from the companies required the collection of primary data, interviews were the core source of 
Table 1 Overview of interviewed firms in the electricity sector (see country abbreviation key in the Appendix, including the respective GDP per capita)

\begin{tabular}{|c|c|c|c|c|c|c|}
\hline $\begin{array}{l}\text { Firm name } \\
\text { (abbreviated name in } \\
\text { text) }\end{array}$ & Type and scope of activities & $\begin{array}{l}\text { Home } \\
\text { country }\end{array}$ & $\begin{array}{l}\text { Year of } \\
\text { start }\end{array}$ & $\begin{array}{l}\text { Size (\# } \\
\text { staff) }\end{array}$ & Sales & Interviewees \\
\hline ASM Terni (ASM) & Production, distribution & IT & 1960 & 350 & $<€ 50 \mathrm{M}$ & $\begin{array}{l}\text { R\&D manager } \\
\text { Head of the network \& innovation } \\
\text { department }\end{array}$ \\
\hline $\begin{array}{l}\text { Electricity Authority of } \\
\text { Cyprus (EAC) }\end{array}$ & $\begin{array}{l}\text { Production, transmission, } \\
\text { distribution, supply }\end{array}$ & $\mathrm{CY}$ & 1952 & 2,200 & $€ 630 \mathrm{M}$ & $\begin{array}{l}\text { Project leader } \\
\text { Network engineer } \\
\text { Transmissions manager }\end{array}$ \\
\hline Utility company 1 & $\begin{array}{l}\text { Production, distribution, } \\
\text { supply }\end{array}$ & ES & 1841 & 17,229 & $€ 24 \mathrm{~B}$ & $\begin{array}{l}\text { Business developer } \\
\text { Distributed generation manager }\end{array}$ \\
\hline Watt+Volt & $\begin{array}{l}\text { Supply, technology } \\
\text { provider }\end{array}$ & GR & 2011 & $51-200$ & $n / a$ & $\begin{array}{l}\text { Head of the supply operations } \\
\text { department } \\
\text { Head of business development } \\
\text { department }\end{array}$ \\
\hline SOREA & $\begin{array}{l}\text { Hydro and PV production, } \\
\text { storage, distribution }\end{array}$ & $\mathrm{FR}$ & 2007 & $11-50$ & $\mathrm{n} / \mathrm{a}$ & Project manager \\
\hline Utility company 2 & $\begin{array}{l}\text { Transmission, distribution, } \\
\text { supply }\end{array}$ & RO & 1998 & 14,000 & $€ 1.4 \mathrm{~B}$ & $\begin{array}{l}\text { Manager of the change } \\
\text { management department }\end{array}$ \\
\hline PH Energia (PHE) & $\begin{array}{l}\text { Supply, technology } \\
\text { provider }\end{array}$ & PT & 2014 & $11-50$ & $\mathrm{n} / \mathrm{a}$ & Manager natural gas market \\
\hline EMSc & $\begin{array}{l}\text { Technology provider, } \\
\text { consultancy }\end{array}$ & UK & 2001 & 100 & $\mathrm{n} / \mathrm{a}$ & Team leader of the $R \& D$ department \\
\hline $\begin{array}{l}\text { SYSTEMS SUNLIGHT } \\
\text { (Sunlight) }\end{array}$ & Storage, supply & GR & 1994 & 770 & $€ 168 \mathrm{M}$ & $\begin{array}{l}\text { Head of the product development } \\
\text { department }\end{array}$ \\
\hline UNE & Storage, consultancy & IT & 2011 & $11-50$ & $\mathrm{n} / \mathrm{a}$ & $\begin{array}{l}\text { Company owner } \\
\text { Head of the product development } \\
\text { department }\end{array}$ \\
\hline ATOS SPAIN (ATOS) & $\begin{array}{l}\text { Consulting, technology } \\
\text { provider }\end{array}$ & ES & 1997 & 100 & $€ 12 \mathrm{~B}$ & Project manager \\
\hline $\begin{array}{l}\text { Virtual Power } \\
\text { Solutions (VPS) }\end{array}$ & Technology provider & PT & 2015 & $11-50$ & $\mathrm{n} / \mathrm{a}$ & $\begin{array}{l}\text { Head of the innovation and product } \\
\text { development department }\end{array}$ \\
\hline $\begin{array}{l}\text { Technology provider } \\
1\end{array}$ & Technology provider & RO & 1992 & 1,300 & $€ 89 \mathrm{M}$ & Senior consultant \\
\hline $\begin{array}{l}\text { TREK Consulting } \\
\text { (TREK) }\end{array}$ & $\begin{array}{l}\text { Technology provider, } \\
\text { consulting }\end{array}$ & GR & 1995 & $11-50$ & $\mathrm{n} / \mathrm{a}$ & $\begin{array}{l}\text { Senior project manager } \\
\text { Project manager }\end{array}$ \\
\hline
\end{tabular}

information. The interviews were conducted with the founders, and product and/or project managers (see the overview of interviewees in Table 1). Interviews were carried out in person, by telephone or through Skype, depending on the interviewee's preference, and they lasted between $20 \mathrm{~min}$ and $1.5 \mathrm{~h}$. A basic questionnaire was used to conduct semi-structured interviews focused on the details of the firms and their representatives (e.g., activities and roles), their business model (e.g., original business model and adaptation to new markets), the energy transition (e.g., how their activities and business model relate to it), the firms' internationalization (e.g., stage, approach and ambitions), and barriers affecting it. Questions were subsequently refined according to recurring response patterns.
In total, we interviewed 21 representatives of 14 firms in two phases (in 2017 and 2018) ${ }^{4}$; in six firms, it turned out to be possible to interview more than one person. The interviews resulted in 170 pages of transcripts, all in English, and transcribed following a 'denaturalism' approach with a focus on the relevant themes indicated above (McLellan, MacQueen, \& Neidig, 2003; Oliver, Serovich, \& Mason, 2005). We also gathered documents available in the framework of the project and publicly available materials (i.e., company websites, news reports, and publicly available reports). These were, however, primarily used only to provide background information on the firms presented in Table 1 and to prepare for the interviews, as the nature of the information was not specific enough 
to explore our research question in sufficient detail. In order to tackle the risks of biased information and of subjective interpretation, we adopted the following measures. On the one hand, we inquired about the possibility of interviewing more informants with different roles in the same organization. This was possible in six cases. The confrontation of the answers provided in the two interviews enabled a solid reporting of facts. On the other hand, we restricted the interview questions to 'factual accounts' (e.g., concerning the firm's business model), in order to minimize the risks of speculation (Martin \& Eisenhardt, 2010).

\section{Data Analysis}

The data analysis encompassed four main stages. The first stage consisted of a deductive analysis of the interview data with a focus on the business model components and their location-boundedness. This first analysis was deductive because we employed as codes concepts derived from the literature (cf. Bohnsack et al., 2014; Rugman et al., 2011), in order to uncover the BMSA of each focal firm. Specifically, we assigned to the data the following codes: value proposition, value network, revenue-cost model, location-bound, and non-location-bound. The coded text was then extracted and examined to find recurring patterns and differences, across cases, about the firms' BMSA location-boundedness, in keeping with Figure 1. In order to assess comparatively the degree of BMSA location-boundedness experienced by each firm, we assigned, for each business model component, 1 point when it emerged as location-bound, 0.5 points when the business model component was partially location-bound (e.g., if minor adaptations were necessary to be competitive in the foreign market), and 0 points when it was described as nonlocation-bound (see Table 2).

The second stage entailed an inductive analysis, driven by empirical insights emerging from the data (cf. Ciulli, Kolk, \& Boe-Lillegraven, 2019; Corley \& Gioia, 2004) about key (potential) host country-related challenges. In particular, we noted that the interviewees highlighted barriers to BMSA recombination faced by the firms in the (potential) host countries; these were described by the interviewees as factors inherent to the foreign markets, which made it highly difficult or impossible for the focal firms to recombine their BMSAs with needed local assets. We thus concentrated on uncovering inductively the factors emerging from the interview data which hindered the bundling of the firms'
BMSAs with location-specific assets in (potential) foreign markets. More specifically, in keeping with the inductive interpretive approach (Ciulli et al., 2019; Gioia, Corley \& Hamilton, 2013; Gioia, Price, Hamilton \& Thomas, 2010), we first recorded a set of terms and phrases which closely represented the raw data and coded them through open coding (Gioia et al., 2010). We then examined similarities and differences between these "first-order codes" (Gehman et al., 2017), and, through axial coding, we grouped them accordingly into second-order themes (Gioia et al., 2010). Finally, we classified the themes into aggregate dimensions until the analysis reached theme saturation (Bowen, 2008; Ciulli et al., 2019) and did not uncover any additional relationships. These concepts reflected the different types of barriers to BMSA recombination highlighted in the interviews. In keeping with the Gioia methodology (cf. Ciulli et al., 2019; Corley \& Gioia, 2004; Nag \& Gioia, 2012; Van Burg, Berends \& Van Raaij, 2014), Figure 2 depicts the data structure that emerged from the inductive analysis of the barriers to BMSA recombination.

We then returned to the coded data, in order to assess which type(s) of barriers to BMSA recombination (regulatory, infrastructure, market barrier) were experienced by each firm, and compared the cases on the extent to which they experienced barriers to BMSA recombination. Similar to the approach adopted to assess the BMSA locationboundedness, we assigned, for each of the three barriers to BMSA recombination, 1 point when the focal firm faced a barrier, 0.5 points when the barrier to BMSA recombination was only experienced by the firm for a few, specific foreign markets, and 0 points when the firm did not face a barrier (see Table 2).

Third, we deductively analyzed the firms' internationalization, by coding the data using the following codes: no internationalization, internationalization with adaptation, and internationalization with no/marginal adaptation. Fourth, to reflect the dimensions examined and analyze the cases comparatively along them, we developed a framework representing, on the horizontal axis, the degree of BMSA location-boundedness and, on the vertical axis, the level of barriers to BMSA recombination. We plotted the cases in the framework based on the assessment conducted in stages one and two. We then examined the position of each case in the framework in relation to its internationalization, captured in the third stage, in order to uncover patterns across cases. 


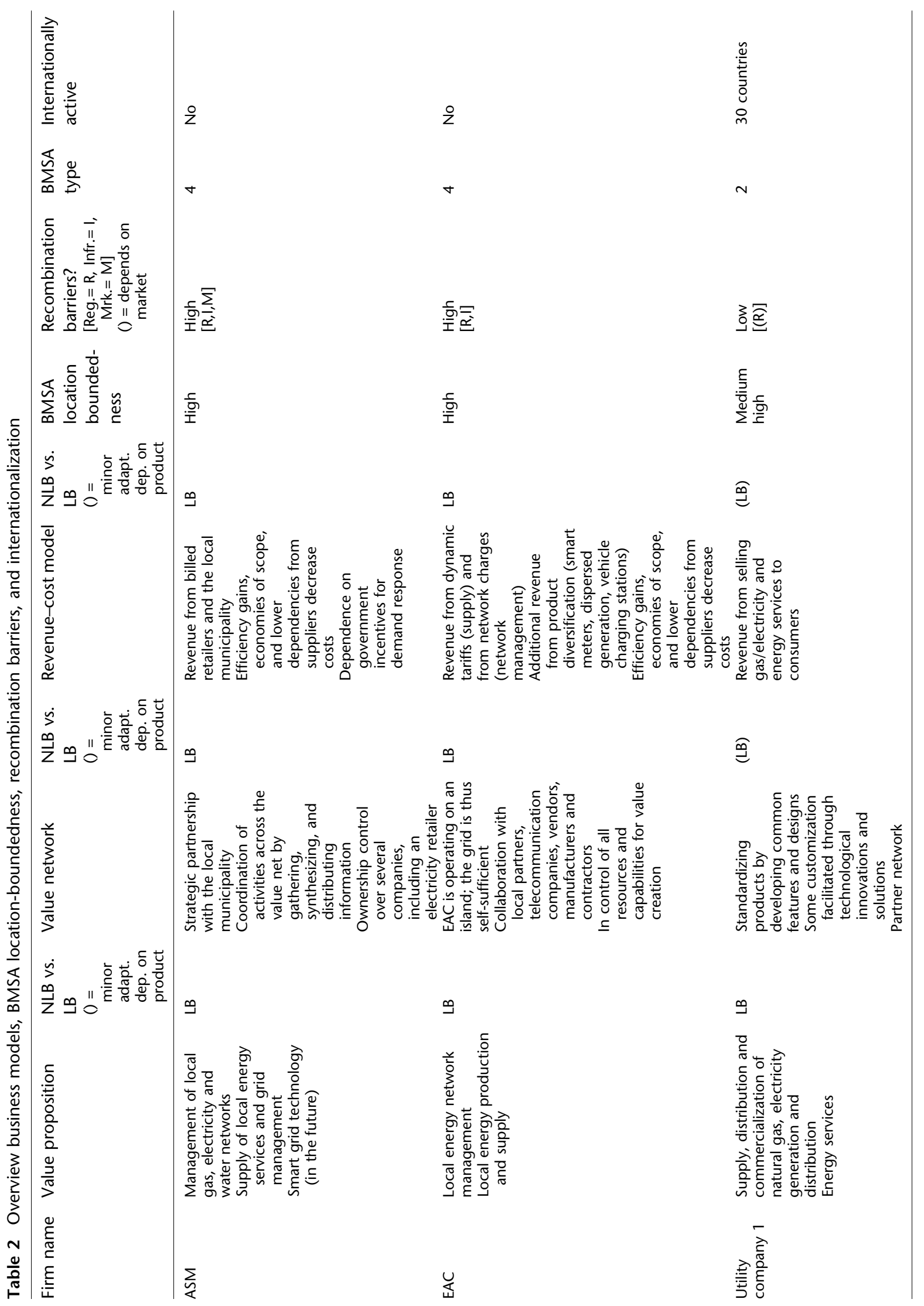



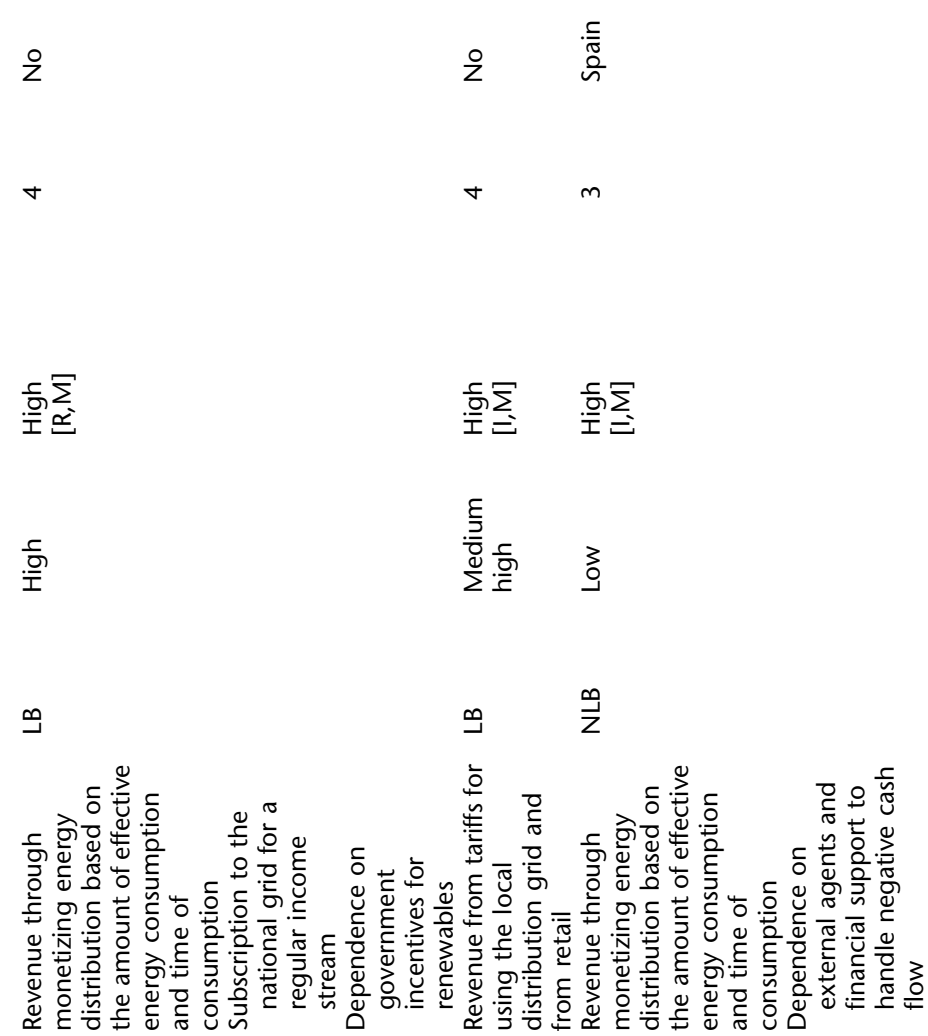

$\cong \quad \stackrel{\oplus}{z} \quad \stackrel{\oplus}{z}$ 


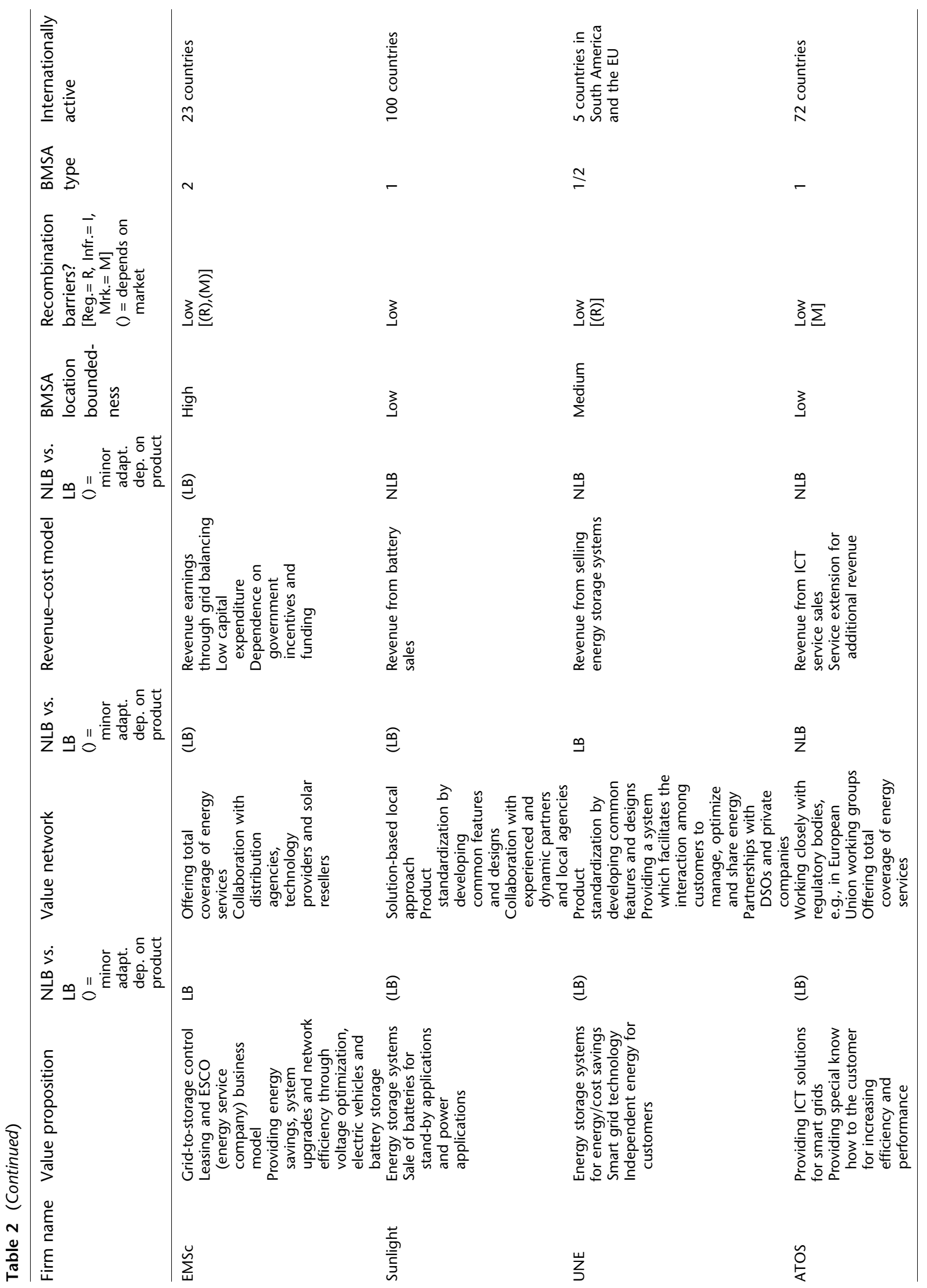




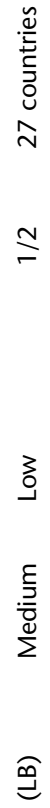

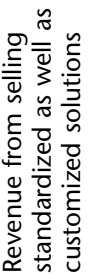

을

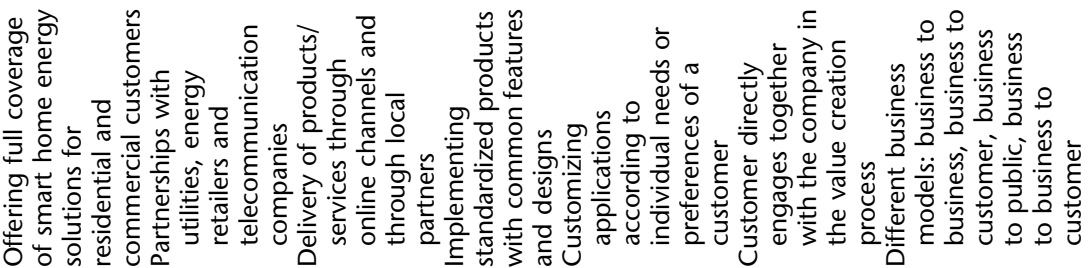

穵

Qิ

बㄹㄹ

อิ
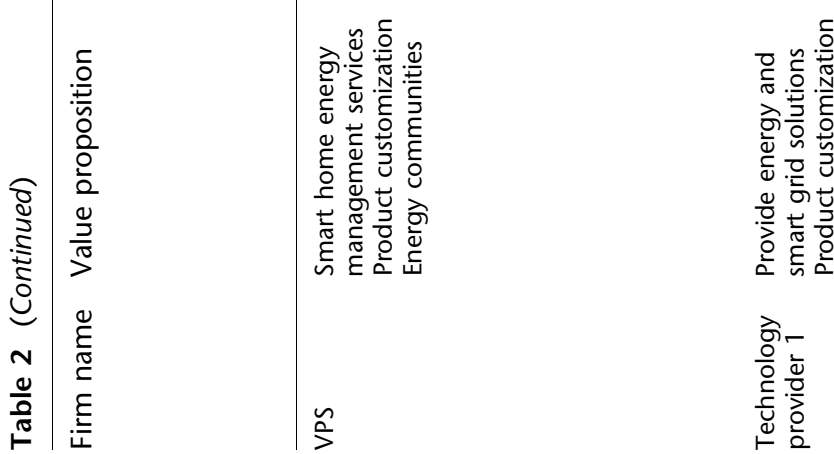


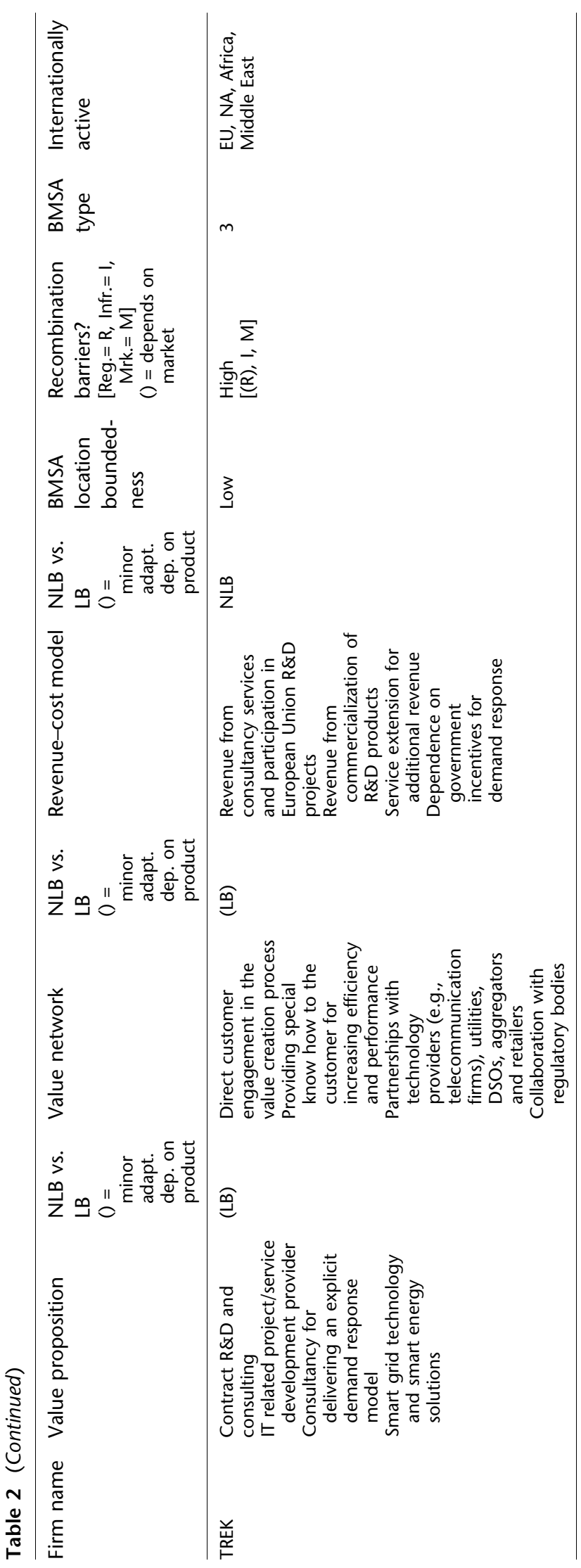

Both the deductive and the inductive analyses were conducted using Atlas.ti software. We ensured the reliability of our analysis particularly through "investigator triangulation" (Denzin, 2017) which consisted of leveraging the three authors' different degrees of engagement "with the data collection and analysis to balance empirical embeddedness with research independence (Gioia, Thomas, Clark \& Chittipeddi,1994; Gioia et al., 2010)" (Ciulli et al., 2019, p. 11). Specifically, the first author, who had direct knowledge of the firms and their context, due to the common involvement in the H2020 project inteGRIDy, and had been in charge of the data collection, carried out the data analysis, by coding the data deductively, in terms of business model components and internationalization, as well as inductively, to uncover the barriers to BMSA recombination. The second author, who had knowledge of business model and IB literature, and the electricity context in general, but had not been involved in the data collection, also analyzed the data deductively and inductively, in parallel and independently from the first author. The outcome of the deductive and inductive coding conducted independently by the two authors presented relevant similarities, but also some distinct interpretations. In line with the qualitative method's approach to intersubjective agreement (cf. Ciulli et al., 2019; Saldaña, 2013; Smaling, 1992), the discrepancies were addressed through discussion and by further analyzing the data until a consensus was attained between the two authors. The third author, with an extensive experience in IB and business model research, was involved in the analysis as a "sparring partner" (Ciulli et al., 2019), in charge of verifying the consistency of the findings and confronting them with the theory. In this way, the whole author team participated, but in different and complementary ways.

\section{FINDINGS}

As outlined in Table 2, the 14 cases in the sample displayed a highly diverse degree of internationalization. Four firms had not expanded internationally, while the scope of internationalization of the other companies ranged from 1 to 100 countries. We set out to understand the role of business models and recombination barriers in (potential) host countries. Based on an analysis of the business model components of the companies in our study, this section presents the findings in three steps. First, we illustrate how the location-boundedness of 


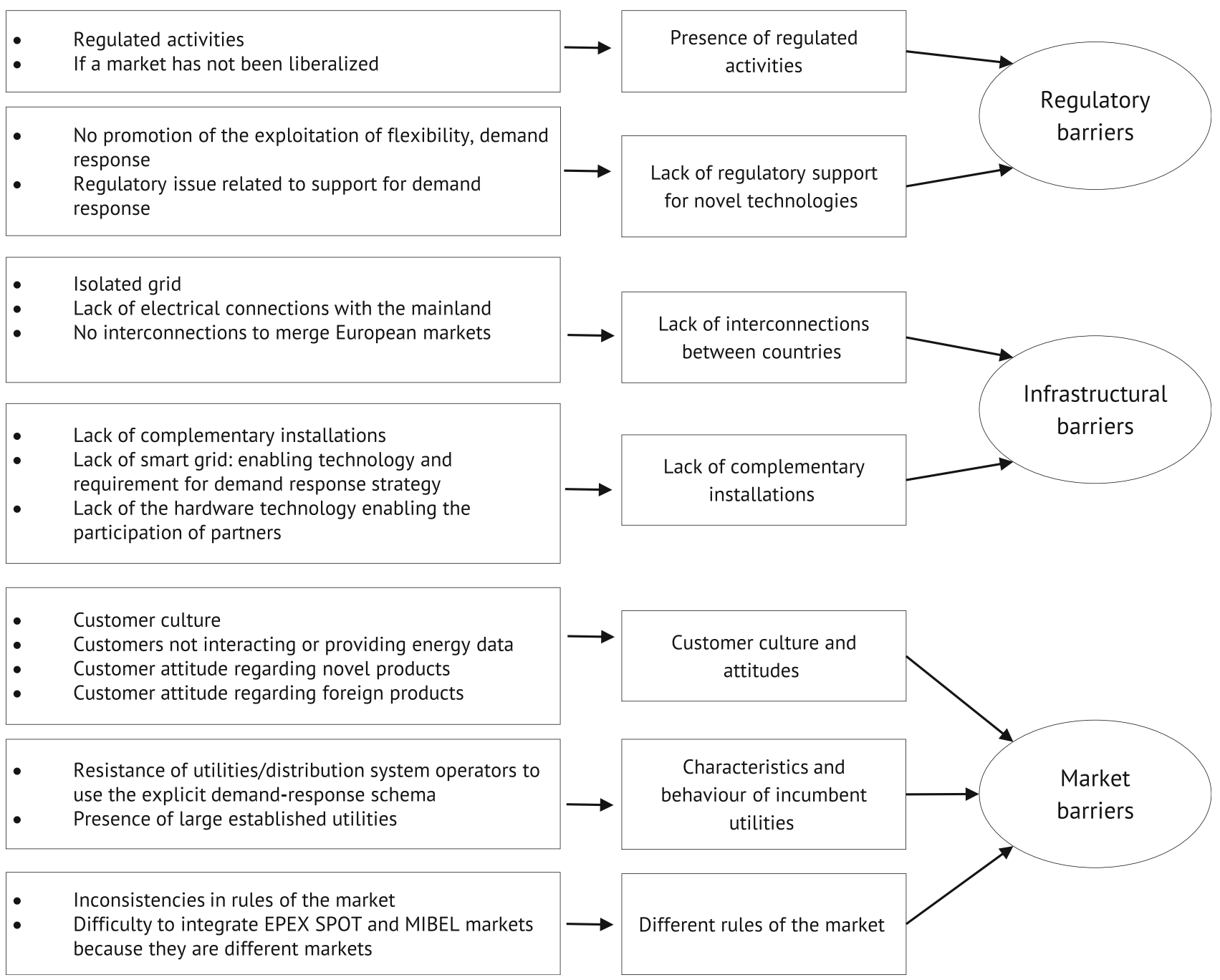

Figure 2 Data structure of the BMSA recombination barriers in the host country

BMSA configurations unfolds for their individual components and then for the business models as a whole. The second subsection sheds light on the different kinds of barriers to BMSA recombination as they emerged from the data. We subsequently explore firms' internationalization in relation to BMSA location-boundedness and recombination barriers.

\section{Location-Boundedness of BMSAs}

When linking Figure 1 to the data, we observed subtler variations in the location-boundedness of the business model components: whereas for some companies the component(s) clearly fitted into the non-location-bound/location-bound dichotomy, others displayed a more nuanced degree of location-boundedness (see columns 3, 5 and 7 in Table 2). In keeping with these insights, we report below the location-boundedness of business model components across the cases.

\section{Value Proposition}

As noted, we found variation in the degree of location-boundedness, with some fitting directly into cells 1 or 2 of Figure 1, and others expressing that some adaptations were needed to be able to compete in foreign markets. Starting with cell 1, the value proposition of firms offering 'traditional' electricity services of supply, distribution, and transmission emerges as highly location-bound. A 
key example is EAC's value proposition, which entails local network management and local energy production and supply, and is specifically tailored to the local setting and to the requirements of its home country. Similarly, the value proposition of ASM is strongly tied to the needs of the local market: they "have to supply energy locally" to customers that include the local municipality, which is also the owner, and retailers. The company notes that its role as distribution system operator "limits [its] position in the world". In the case of another distributor system operator (Utility 2 ), we also found a value proposition which consists of providing local energy distribution services, and thus fundamentally bound to local customers and their needs.

Other companies indicate possibilities but only if major adaptations are made. Utility 1 highlights that its electricity generation services need to include a different generation mix depending on the country, and that in those countries where the construction of new electricity generation plants is assigned through auctions, the company has to abide by the specific requirements. Novel value propositions in the electricity sector that entail the provision of smart technologies, such as those related to smart metering and demand-response algorithms, may be location-bound. An example is EMSc, which pointed at regional- rather than country-level location-boundedness. In particular, to enter Southeast Asia and satisfy the requests of the customers in this host region, the company explains the necessity to make changes to its solutions for the electricity infrastructure, while "in Europe the product is generally quite similar".

Some value propositions emerge as having a core that is non-location-bound, coupled with just some location-bound features which require adaptations to host locations (cell 2). For instance, several technology providers report that, while the essence of their value proposition (e.g., energy savings as in the case of VPS), remains the same across all countries, they must adjust selected features to fit host-country specificities (e.g., different plugs are needed for its products in the home country, Portugal, compared to the UK). Technology provider 1 explains having a "specific value added" with regard to its software, and providing solutions that must be fine-tuned to the individual customer's requirements. Similarly, UNE states that its product, a storage system, is the same in every country, with only the software needing changes. Along the same lines, ATOS explains that only "minor things change between markets", and, for its IT services, it only "need[s] to adapt to how data are produced" and "how to collect data" in host countries. These companies can thus rely on offering relatively standardized products, with some modifications necessary to fit foreign markets' specifications. For TREK and Sunlight, the value proposition is even less location-bound, and thus standard products/ services can be transferred to foreign countries with minor modifications if needed by particular markets. As stated by TREK, "the core of the business is providing IT services in the energy domain, so the end-to-end solutions can be easily replicated in any market".

\section{Value Network}

The value network also shows different degrees of location-boundedness across the cases. For example, ASM, SOREA, and EAC, active in electricity distribution and/or transmission, face a high location-boundedness (cell 3), as all their core resources, activities, and partners are entrenched in the home-country local environment. A fundamental asset for all three firms, as distribution service operators, is the local network infrastructure they manage in the home country. They are also strongly embedded in a local network of actors. The main actor for EAC, as a public company, is the government: "the government is our boss"; key partners are telecommunication companies, vendors, manufacturers, and contractors. A core strategic partner in ASM's value network is the local municipality, which owns the company, gives it the authorization to manage the local networks, and is not particularly interested in expanding the business (model) internationally. Despite their current high embeddedness in the local context, digital technology could create some opportunities for these companies to attain a partially nonlocation-bound value network in the future. In this regard, ASM suggests the creation of a European platform with algorithms and other software in the cloud, thus realizing common expertise for other countries. It might become a global approach with the possibility to consume energy locally. Although "the grid is local, the smart grid can be international", while the algorithm and tools are developed through a "European approach."

The location-boundedness of the value network of technology providers is lower than the previous group of firms, and in particular concerns the partnerships for the commercialization of their products and services. For example, EMSc, 
Technology provider 1, TREK, Sunlight, and VPS highlight the necessity to establish a network of local partners when entering foreign countries. VPS stated the need for local partners with knowledge of the market and of the legal requirements for delivering its technology; Technology provider 1 likewise pointed at building "strong partnerships on the local market". According to TREK, local partnerships can involve both technological partners (e.g., specific vendors or retailers to integrate TREK's product in their offer, taking advantage of the existing channels) or utilities that help to implement its demand-response service. Notable is the case of EMSc, which emphasized the location-boundedness of not only individual partners but also its whole distribution model. Indeed, EMSc's distribution model in Europe, which entails relatively small distributors, does not fit the markets in Southeast Asia that require the involvement of local mass distributors. Similarly, the changes to be made by Sunlight for its value network, specifically with regard to the commercialization of its products, depend on the foreign markets. In $\mathrm{EU}$ countries, products can generally be offered directly to customers, while in other countries partnerships with local agents are needed, particularly due to customers' trust concerns. ATOS, PHE, and Utility Company 2 are most clearly positioned in cell 4 , as their value network requires minor to no adaptation to foreign markets.

\section{Revenue-Cost Model}

Similar to the preceding two business model components, the revenue-cost model also shows nuances. Companies for which we found substantial location-boundedness (cell 5) include EMSc: while in its home country, EMSc does not need support for its activities, to be able to operate in the US, subsidies from the state or the distribution system operator would be required given much lower electricity prices. Another relevant example is ASM: because part of its revenues is generated from the services provided to the municipality, which also owns the firm, and it is dependent on government incentives for demand response, international expansion may only be possible with adaptations to the revenue model.

More limited location-boundedness applies to Technology provider 1, which mostly observes some differences in costs across markets, and VPS, which argues that, depending on the market, it may have to adjust revenue streams. Also, adaptations are said to impact VPS' costs and/or revenues, for example, due to the need to involve an 'expert' in charge of advising companies on the contract in Spain, as that is also done by competitors.

For several companies (especially ATOS, PHE, Sunlight, TREK, Watt+Volt), the revenue-cost model is non-location-bound (cell 6). Watt+Volt, for example, relies on revenues from billed customers and energy charges, as well as additional revenues from service extensions, a model that would not require modifications in foreign markets. Likewise, ATOS obtains revenues from the sales of ICT services and service extensions, which does not need to be adapted to host countries. This also applies to Sunlight, as its revenue-cost model is based on selling batteries.

\section{Overall BMSA Location-Boundedness}

Shifting from the individual components to the business model as a whole, our company cases allow us to determine the overall BMSA locationboundedness for each respective firm. To illustrate, inspired by Casadesus-Masanell \& Ricart's (2010) activity system perspective, Figure 3 visualizes two simplified business model configurations, reflecting in light and dark colors the location-boundedness of the BMSA of ATOS and EAC (with locationbound being marked darker).

A cross-case comparison of all firms in the sample uncovered three main groups of configurations. The first group includes firms with a high degree of location-boundedness, because two or all three business model components need to be significantly adapted and recombined to be competitive in foreign markets. It encompasses many firms active in the transmission, distribution and/or supply of electricity (e.g., SOREA, ASM, and EAC), as well as a technology provider (EMSc). A second group, which comprises technology providers and consulting firms, such as PHE, TREK, and ATOS, is characterized by low BMSA location-boundedness. They can thus transfer their BMSAs to host countries with very minor adaptations. Finally, we observed cases (UNE, VPS, Technology provider 1) which are 'in between' the other two groups in terms of BMSA location-boundedness, as they need some degree of recombination and adaptation when entering foreign markets.

\section{Barriers to BMSA Recombination in the Host Country}

In addition to different degrees of location-boundedness, the analysis of the cases also revealed various barriers in the host country that may 


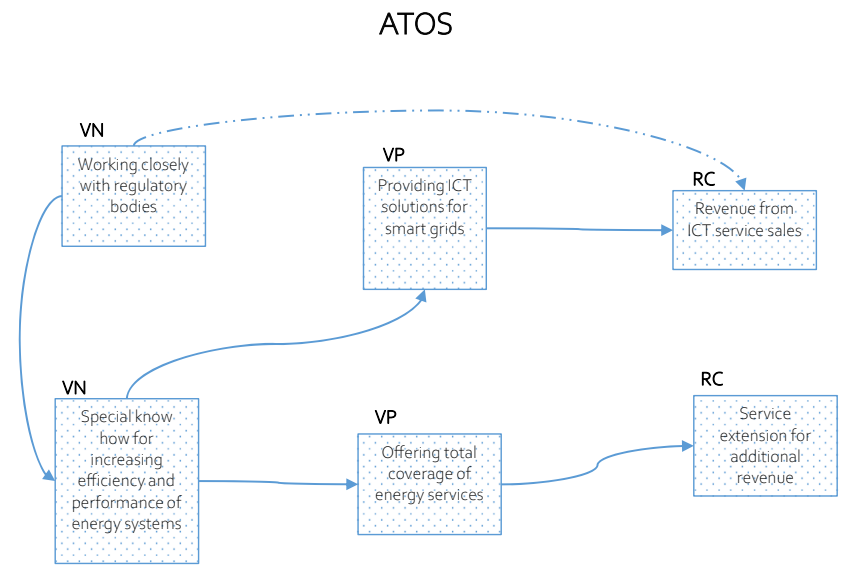

Boxes: Business model components $\rightarrow$ Value proposition [VP], Value network [VN], and Revenue-Cost-Model [RC] Arrows: Connection between business model components (dashed = indirect/delayed connection) Color: Location-bound (dark) vs. non-location-bound (light) component

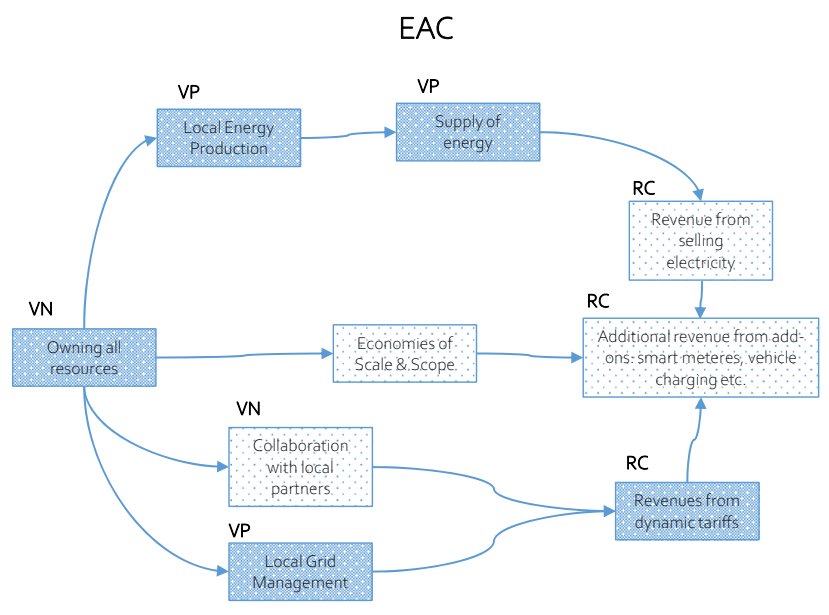

Figure 3 Exemplary business model configurations of ATOS and EAC

complicate recombination of firms' BMSA with local assets. The barriers to BMSA recombination in foreign countries are factors, inherent to the host countries, which hinder the bundling and "melding" (Pitelis \& Verbeke, 2007) of the firms' BMSA with local assets. These barriers either prevent the focal firms from accessing complementary assets present in the foreign market or they obstruct the existence of location-specific assets altogether. Three main kinds of recombination barriers emerged through an inductive interpretive approach (Gioia et al., 2010), as described above, from our data: regulatory, infrastructural, and market barriers, which we present below, using illustrative examples and quotes.

\section{Regulatory Barriers}

A firm faces high regulatory barriers to BMSA recombination when regulations in a (potential) foreign market impede the bundling of the firm's BMSA with local assets. A key regulatory barrier faced by the focal firms is represented by the presence of a regulated and non-liberalized electricity sector in a (potential) host country. As Utility 1 puts it:

\footnotetext{
...we have the knowledge and know-how [...], we have been taking advantages of the differences, adapt the strategy to each country and project, and so we see the regulatory as the biggest barriers.
}

It notes that, while in (more) liberalized countries, there is a need to adapt the BMSAs to the local context, it is not "a big problem"; in other countries, there are much more serious regulationrelated recombination barriers hindering entry.

VPS, a technology provider, is affected by the degree of liberalization of the market for just one of its products, KIPLO, for which the recombination barriers are very high and hinder the company from expanding there. Another technology provider, TREK, highlights the presence of regulatory barriers, albeit not tied to liberalization but rather to policymakers' support for novel electricity-related technologies, which impact its entry in foreign markets:

\section{for the moment, not only in Greece but in many places around Europe [the regulatory framework] does not yet promote the areas that we are trying to develop most, which is the exploitation of flexibility [and] demand response.}

This regulatory barrier makes it challenging for TREK to bundle its non-location-bound BMSAs with local complementary assets in multiple countries. Regulatory barriers to recombination, related to demand response, are also underlined by EMSc with respect to its storage solutions: "demand response is regulation, so it is a regulation issue". Notably, some providers of energy-related technologies, e.g., ATOS, UNE, EMSc (for the voltage optimizer solutions, see below), and Sunlight contend that they do not face significant regulatory barriers to BMSA recombination in general or in specific markets. ATOS argues that they face low recombination barriers with respect to regulation, as it stated, "we only deal with ICT-related topics, we are relatively independent from the regulatory 
framework of individual countries". This is comparable to UNE's observation concerning South American markets, where it sells a system that is not connected to the public grid: "we are not restricted, we have no strict rules". Similarly, EMSc notes "regulation is not a problem" for its voltage optimizer product. Sunlight has not faced any regulatory barrier hindering it from selling its batteries in other countries.

\section{Infrastructural Barriers}

A few companies mention that they are confronted with relevant infrastructural barriers in (potential) host countries, which are specifically related to the absence of "interconnections". These infrastructural shortcomings impede the firms from combining their BMSAs with local assets in foreign markets. A case in point is EAC, an electricity firm from Cyprus, which faces high barriers to recombination, due to the lack of electrical connections with the mainland that hinders its internationalization. It explains the context as follows:

\begin{abstract}
we are an isolated electricity system [...] we are not currently involved in international markets and I do not think that it is that easy to be involved in such markets. [...] There is some project for the electrical connection for Cyprus through a power line from Israel to Greece [...] but before the implementation of that project I do not think that we will be involved in international markets in any other way.
\end{abstract}

PHE, an electricity supplier and technology provider, has also experienced recombination barriers related to the lack of infrastructure, specifically to the absence of "physical connections to transport the energy" between the MIBEL, i.e., the Iberian electricity market, including Spain and Portugal, and other European electricity markets:

\footnotetext{
We are trying to merge all of the European electricity markets, one European hub, but that is not easy because we do not have interconnections and we do not have a lot of capacity in interconnections in very many countries.
}

In its international expansion, TREK instead faces barriers related to "the lack of complementary installations" for its IT services in several countries, i.e., the lack of "the hardware technology that enables the smooth and non-intrusive participation of residential and commercial partners in the automated demand-response schemes". Due to this inadequacy in the host country's infrastructure, TREK faces barriers to bundling its BMSAs with local assets provided by partners in numerous (potential) host countries. More specifically, the service offered by the company builds on the smart grid, which is "an enabling technology and a requirement for TREK's demand response strategy"; its absence thus represents a significant recombination barrier.

\section{Market Barriers}

Some companies in the sample highlighted the presence of market barriers to BMSA recombination; these are hindrances inherent to local markets in (potential) host countries, which impede the bundling of the firms' BMSA with local assets. The importance of market barriers is highlighted especially by TREK, which refers to "the market viability via market models" as a main pre-requisite for its BMSAs. In particular, it notes that utilities and distribution system operators are not always open to using demand-response schemes even if allowed by the regulatory framework. This resistance results in the absence of complementary local assets needed by TREK. Interestingly, TREK seeks to eliminate these barriers to BMSA recombination with local assets by participating in working groups and initiatives as well as interacting with stakeholders to promote further adoption of demandresponse schemes. Interestingly, Watt+Volt also mentions experiencing market barriers to BMSA recombination in multiple potential host countries, especially related to the presence of large established utilities, such as EDF in France. PHE instead stresses inconsistencies in the "rules of the market", particularly between, on one side, the EPEX SPOT markets, which cover Central Europe, and, on the other side, MIBEL, which includes Spain and Portugal: "it is different markets and it is difficult to integrate everything".

In some cases, what the companies called "cultural" barriers emerge as another important marketrelated hurdle to BMSA recombination in foreign markets. One has to do with data privacy concerns, affecting firms with a BMSA relying on smart technology; a smart technology firm needs the active involvement of the local customers, because it has to bundle their 'assets', i.e., data, with its non-location bound BMSA. ATOS mentions "customer culture" to act as a recombination barrier in this respect, stating that, whereas some customers "are accustomed to share data and interact with services provided", others are "not reactive" or "not interacting or providing energy data", and "just willing to get energy". It notes that companies must thus "pay attention how customers are used to work or behave": there are some "proactive users" 
who manage their homes and appliances; yet, if customers are not interacting, companies will probably "fail". Indeed, the resistance of customers to share their location-specific assets needed by the firms, i.e., data, represents a critical barrier to BMSA recombination for smart technology firms. Another barrier is said to consist of the "cultural attitude" towards novel products or their foreign origin. As highlighted by the technology provider, EMSc, skepticism towards new electricity-related products is likely to negatively influence their BMSA recombination in some foreign countries.

\section{BMSAs and Internationalization}

Our analysis shows that the BMSA as well as barriers to BMSA recombination have an influence on the internationalization of the cases. Figure 4 presents a framework that depicts the different approaches by combining, on the horizontal axis, the degree of BMSA location-boundedness with, on the vertical axis, the degree of BMSA recombination barriers.

Firms in cell 1, including ATOS, SUNLIGHT, and Watt+Volt, engage in internationalization by, essentially, transferring their BMSA. These firms have a low BMSA location-boundedness which allows them to replicate their business model in foreign countries with marginal modifications. They also face low recombination barriers in a set of markets, which makes it possible for them to leverage the opportunities offered by the energy transition in international markets, and engage in bundling their business model with the few local assets they need. ATOS, for example, undertakes only limited BMSA adaptations in the European countries that it enters, as only "minor things that change between markets" must be addressed. It has been able to exploit the diffusion of smart grids, triggered by the energy transition, by recombining its non-location-bound BMSA with these local assets. A similar case is Sunlight, which profited from the energy transition as it increased demand for energy storage. It can transfer its BMSA to foreign markets with limited modifications, and has benefitted from the absence of recombination barriers. For instance, an increase of intermittent renewable energy sources in combination with generally old, unstable grids in some countries, has given Sunlight the opportunity to deploy its BMSA and to recombine it with local assets in multiple international markets. It sells mostly a standard product while adapting some specifications for particular markets and, depending on the country, uses subsidiaries, agents or direct sales. It has thus been able to "work closely with experienced partners" and "implement a solution-based

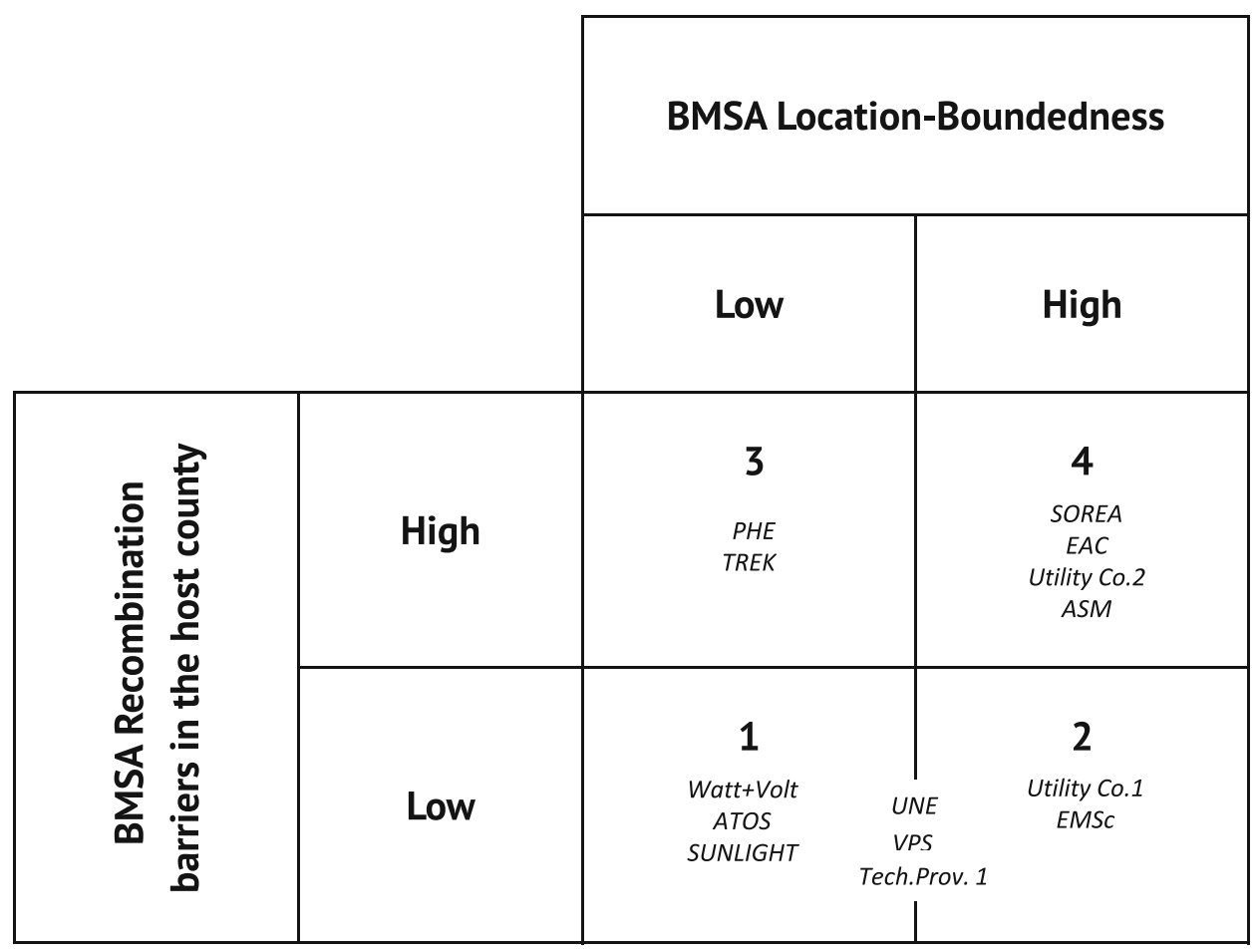

Figure 4 Case companies plotted in a framework of BMSA location-boundedness and recombination barriers 
approach locally, by carefully identifying and promptly responding to specific customer needs". An outlier in cell 1 is, in a way, Watt+Volt, which has only internationalized into two countries. Despite its low location-bound BMSA, it faces one important type of recombination barrier, which is market-related, in view of different market rules and the presence of incumbent utilities in (potential) host countries.

Firms in cell 2 have internationalized by adapting their BMSA to their host countries. These companies are confronted with a high degree of BMSA location-boundedness in some or all foreign markets, which requires them to recombine their BMSA with local assets in order to also be competitive in these countries. At the same time, they can handle recombination barriers in all or many markets to a sufficient degree, in the sense of not impeding their access to local assets. For instance, facing high location-boundedness and low recombination barriers, EMSc has adapted its BMSA and expanded in Southeast Asia and Australia, where it changed its distribution model and amended its product to fulfil the requests of local customers. EMSc sees energy transition as creating opportunities for recombination with local assets in foreign markets, because its solution enables significant savings compared to using the old grids. Sometimes, the seriousness of BMSA recombination barriers depends on the country in question. An example is Utility 1: its business model-related decisions are being been shaped by the energy transition and, in those locations where it encounters low recombination barriers, has "been taking advantage of the differences", "design[ing] the business model according to the local market", also in collaboration with many partners, with the composition depending on the country. Although being able to adapt its BMSA in this way, it still faces challenges in entering countries with high regulatory barriers to recombination. The energy transition had thus a clear effect for the internationalization of these companies.

Next to the cases that are clearly attributable to one cell, we observed three firms in our sample that fall in between cells 1 and 2, as they have a medium degree of BMSA location-boundedness. For instance, Technology provider 1's level of change in its BMSA, which particularly concerns the value proposition and value network, is contingent on the specificities of the market. As a result, the company has, "different approaches to commercialize our solutions to different markets". In a similar vein, VPS, due to its medium locationboundedness, entered selected foreign markets by undertaking a number of adaptations and by bundling its BMSA with local partners. UNE, the third firm that falls in between cells 1 and 2, also devised a process to adjust its BMSA: "we can change the use of the system without changing the hardware of the system because we have made software just to [adjust to] all the needs of the customer."

Firms in cell 3 have low BMSA location-boundedness, but the barriers to BMSA recombination are high in multiple foreign countries and impact the entry decision. For example, TREK expands to foreign markets with limited BMSA adaptation, as "the end-to-end solutions can be easily replicated in any market". However, the different levels of support for demand response across countries, epitomizing divergent severity of regulatory barriers, "do affect the entry of technology providers as TREK". Another example in cell 3 is PHE. They internationalized into Spain, as it has low BMSA location-boundedness and faces lower recombination barriers in this market. For the limited adaptation the company had to undertake, it accessed the services of local actors: "we contracted Spanish people, with knowledge in the market, to work on that $[\ldots .$.$] so the adaptation is not too big". How-$ ever, recombination barriers, particularly related to infrastructure, increase for PHE outside the MIBEL market, and make its further internationalization much more challenging, as the company noted, impeding entry to other foreign countries. Thus, for firms in cell 3, the energy transition has opened up new opportunities to internationalize, but only to specific markets.

Finally, firms in cell 4 include utilities in charge of electricity distribution, transmission, and supply, such as ASM and EAC, which have not expanded internationally but remained local. These firms are characterized by high BMSA locationboundedness, as their business model components are deeply rooted in their home-country environment. As ASM explains: "the energy produced in Terni cannot be sent to another country, it is impossible [...] The grid is local." They also face high recombination barriers, particularly related to regulation and infrastructure, which hinder their internationalization. For these companies, the energy transition has not had a profound enough impact on their BMSA for them to consider internationalization; in a way, they are remnants of the 'old centralized energy system', whereas firms in 
cells 1, 2 and 3 can be considered exemplary for the 'new energy system'.

\section{DISCUSSION AND CONCLUSIONS}

Using the energy transition as empirical context, this study has explored the role of BMSAs in the internationalization of firms. The energy transition is a unique phenomenon that unites technological, regulatory, and organizational dynamics on an international scale. We conceptualized BMSA as a business model-related specific advantage, thus bringing insights from strategic management research on business models (e.g., Casadesus-Masanell \& Ricart, 2010; Massa et al., 2017; Zott \& Amit, 2010) into the IB field. We then uncovered the barriers to BMSA recombination in host countries, connecting the BMSA concept with the new internalization theory (e.g., Grøgaard et al., 2019). Building on the findings of our qualitative study, we contend that the degree of BMSA locationboundedness, together with the level of barriers to BMSA recombination, have three important implications for a firm's internationalization process.

First, the BMSA concept, by integrating the whole configuration of value creation and capture of a firm, proposes a systemic view of its competitive advantage. While some IB studies have referred to the business model as a type of FSA, we argue that its full potential for capturing the complex and interrelated sources of a firm's competitive advantage has not been realized to date, as the literature has merely concentrated on analyzing FSAs as single resources or capabilities owned by a firm. Yet, by showing that the degree of BMSAs' locationboundedness depends on the transferability of the three interrelated core business model components, which varies across firms, we uncover the complexity of the configuration that a firm has to take into account when deciding whether and how to internationalize. This suggests that an internationalization decision does not just depend on whether a specific resource or capability can be exploited internationally but, rather, on whether a business model as a whole enables the creation and capture of value also in foreign markets. With its systemic and modular nature (Teece, 2018; Zott \& Amit, 2010), the BMSA concept thus helps the understanding of a firm's internationalization decisions as based on the entire "architecture of the value creation, delivery, and capture mechanisms" (Teece, 2010, p. 191), and its efforts in disassembling and re-assembling these interrelated mechanisms in order to enter foreign markets. Our findings suggest that, while firms with a nonlocation-bound BMSA have a high degree of internationalization, different degrees of BMSA location-boundedness may not necessarily lead to different internationalization decisions. That is, a firm with a high degree of BMSA location-boundedness needs to assess whether the adaptation and recombination of the location-bound components engenders substantial costs and risks for the coherence of the whole configuration of value creation and capture. For 'traditional' utilities - in charge of the transmission and distribution of electricity and with the (local) government involved in all the business model components - their high BMSA location-boundedness is likely to entail high risks and costs of adaptation and recombination in foreign markets. However, for new digital entrants, such as firms offering electricity-related services, adaptations of the business model configuration are likely to be less costly and can be worth the risk, especially if the market to enter is attractive.

Second, our study highlights that - in addition to the degree of BMSA recombination that is required - internationalization is affected by the extent to which this BMSA recombination is actually possible. Our findings indicate that firms often face barriers to BMSA recombination in a foreign market that hamper the creation of "the right [BMSA] mix" (Narula \& Verbeke, 2015; Rugman et al., 2011). This corroborates and expands the conceptual work of Hennart (2009), who pointed to hurdles tied to the accessibility of complementary local assets in the host country. The cases reveal that the recombination of specific business model components in foreign markets is affected by an array of barriers, with relevant implications for firms' international expansion decisions. The three types of recombination barriers emerging from our inductive analysis, i.e., regulatory, infrastructural, and market, resonate, to a certain extent, with country-specific factors identified in prior IB studies. For example, Lu et al. (2014) have identified regulatory quality in host countries as affecting firms' location choice, while multiple studies have explored the role of culture in internationalization (Caprar, Devinney, Kirkman \& Caligiuri, 2015). Our study adds to this literature by conceptualizing barriers which in particular affect the recombination with local assets in foreign markets and internationalization decisions, thus contributing to new internalization theory. Notably, we found that firms which are tied to the 'traditional' centralized energy system 
are more likely to face higher recombination barriers in (potential) host countries than firms that rely on or offer novel technologies. This diversity suggests that the energy transition is experienced differently across electricity firms: those with 'traditional' business models (e.g., transmission of electricity) tend to experience a fragmented and localized electricity market - in particular when regulation and infrastructure have not yet been affected by the energy transition - which hampers their international expansion; firms with novel business models, instead, generally experience an international, relatively integrated, electricity market, which facilitates internationalization.

Third, building on the two dimensions outlined above, we proposed a framework (Figure 4) that encompasses both dimensions and plotted the cases in the framework in order to uncover implications for firms' internationalization. Drawing on our cases, we conceptualize the horizontal dimension as a continuum, where BMSA location-boundedness is high if, in order to rely on the BMSA in a foreign market, substantial changes are necessary across all business model components (and low when just minor adaptations are required). Likewise, BMSA recombination barriers in the host country can also be seen as a continuum. We contend that the level of BMSA recombination barriers is high when firms face multiple barriers that are difficult to overcome. They are, instead, low when local assets are easily accessible, making BMSA recombination viable with negligible or no hurdles. By relating the cases' positions in the framework to their internationalization, we advance internationalization theory, because we propose that firms' internationalization decisions are affected, concurrently, by the extent to which the BMSA is location-bound and by the severity of the barriers to BMSA recombination in foreign markets. More specifically, the findings allow the identification of a set of implications for firms' internationalization.

A firm that can transfer its BMSA with no or just minor adaptations to foreign markets, encountering no significant impediments to BMSA recombination (cell 1), may internationalize relatively easily by simply transferring its business model to the host countries, given the absence of substantive hurdles. This firm is thus likely to have a high scope of internationalization. In a scenario of high BMSA location-boundedness and low barriers to BMSA recombination (cell 2), the costs and risks of adaptation of the whole business model configuration to foreign markets will determine whether internationalization is going to take place, and, if so, where. Indeed, due to the business model's modularity, a high need for business model adaptation may not necessarily hamper a firm's internationalization, if it has the flexibility to separate and reintegrate the business model components. As suggested by the case of Utility Company 1 and its different generation mix, for example, a firm can leverage its portfolio of value propositions that can be selected and 'assembled' with the other business model components depending on the specific host country. With low BMSA location-boundedness but high barriers to BMSA recombination in the host country (cell 3), a firm benefits from a business model that can be transferred internationally without major changes, but, at the same time, faces challenges in accessing specific local assets in (multiple) foreign countries. The firm is thus likely to undertake limited internationalization, if any, targeting only the markets where the barriers to BMSA recombination are lower or absent. If a firm is positioned in cell 4, where both the BMSA location-boundedness and the barriers to BMSA recombination are high, it is very likely that the firm will remain local, as the challenges and costs of internationalization are prohibitive, because it would have to bear major costs and risks of both substantially adapting its business model to fit foreign markets and tackling the significant recombination barriers faced.

The findings also revealed cases positioned in 'inbetween' cells (between cells 1 and 2), exhibiting a medium degree of BMSA location-boundedness and low barriers to BMSA recombination. The low barriers to BMSA recombination enable firms to expand internationally by, for example, establishing collaborations with local partners. We indeed observed, in the case of VPS and Technology provider 1, that, when entering foreign countries, a part of their value network becomes locally embedded, with the boundary-spanning nature of their BMSA being spread across borders. Also, the medium degree of BMSA location-boundedness means that the firms do not encounter major costs in modifying the business model components, and they can, for example, relatively easily 'fine-tune' the value proposition to foreign market needs.

Connecting the findings in particular with the energy transition, our cases indicate that companies providing novel electricity-related technologies are more likely to benefit from low costs of adaptation of the value proposition and network to 
local market needs. In such situations, limited impediments to BMSA recombination, coupled with low adaptation costs, will encourage a firm to engage in a wide internationalization. More generally, the findings suggest that firms embedded in the new energy system, which is triggered by the energy transition and characterized by decentralization and smart technologies, are more likely to be positioned in cell 1 or cell 2 . Firms that instead have a business model that is attached to the 'old', centralized energy system face higher costs and challenges to internationalize, and they are thus more likely to be positioned in cell 4 . These patterns hint at the role that novel technologies may play in the internationalization of firms in the electricity sector. This resonates with recent interest for ICT and digital technology in IB (e.g., Alcácer, Cantwell, \& Piscitello, 2016; Coviello et al., 2017), and points at further research areas, to which we will pay attention below, together with contributions, implications, and limitations.

\section{Contributions, Implications, and Limitations}

Our study contributes to current debates in IB in several ways. First, it advances insights by proposing the BMSA construct as a novel, compound, and comprehensive type of FSA. By uncovering the three functions of a business model - i.e., the articulation of the value proposition, the design of the value network, and the configuration of the revenue-cost model - as well as their locationboundedness, we offer a novel perspective on the FSA architecture for international expansion. While exploratory in nature, our paper in this way connects the IB literature and business model research, thus explicating and elaborating on brief, though notable, references to the business model as an FSA in earlier articles (e.g., Hennart, 2009; Verbeke et al., 2018), as well as responding to recent calls for more attention to this topic.

Second, the study adds to existing work on FSA recombination by shedding some more light on the existence of barriers in the host country that may hinder such recombination. It also illustrates that the intensity of these barriers varies, and can influence the opportunities to internationalize, making it (virtually) impossible or (highly) viable. Third, by proposing a framework that relates BMSA location-boundedness to BMSA host-country recombination barriers, we outline how these two dimensions may affect a firm's international expansion.
Furthermore, our paper contributes to research on internationalization in the context of the energy transition by showing how firms in the electricity sector experience different patterns, due to their diverse BMSAs. In particular, we suggest that the diffusion of novel electricity-related technologies, driven by the energy transition, is likely to have an impact on whether and how firms in the electricity sector expand internationally.

In this way, our study has implications not only for IB scholars but also for those involved in MNE strategy and policymaking. First, it can offer insights for founders of early-stage new ventures who are (about to) configure their business model, which ideally should be one with as little as possible location-bound components for gaining international traction and enticing investors. Second, given the high risks and low returns of investing in ventures in this industry (Gaddy, Sivaram, Jones, \& Wayman, 2017), scrutinizing the BMSA can be valuable for those wanting to assess scalability - usually seen as positively influenced by higher transferability, thus increasing attractiveness. Third, our conceptualization of the BMSA enables an analysis of which host markets may require least adjustments to the business model of established firms when expanding internationally. It can thus be seen to add a specification to the original managerial motivation for the very business model concept, which according to Sabatier, Mangematin, \& Rouselle (2010, p. 444) stemmed from the quest "for a strategic tool that could take into account the problems of how to address several markets".

The complexities for firms in handling all these differences between countries might also draw policymakers' attention to the relevance of market liberalization in the context of the energy transition. Despite having been underway for over two decades, as noted by Pepermans (2019, p. 5), "a European internal electricity market for electricity [...] has not been realized yet". The scattered and uncertain policy landscape hampers venture creation and scaling-up, especially across borders. Based on our study, regulators might prioritize the removal of particular barriers to recombination.

Despite its contributions and implications for research and practice, we want to acknowledge limitations of our work and link them to possible areas for future research. While our study proposes the BMSA as providing a systemic and boundaryspanning perspective, the cases examined were centered on an individual focal firm. The rise of 
novel digital technologies, such as blockchain, in the electricity sector and in other sectors, is triggering the emergence of decentralized business models, where multiple actors are involved in value creation and capture, without any actor having a dominant position over the others. The internationalization of these novel kinds of business models deserves further investigation, and will require a shift from business-model related FSAs to "business model-specific advantages".

Moreover, as our research is exploratory in nature, it would be helpful if follow-up studies could investigate the impact of BMSAs' locationboundedness and/or BMSAs' recombination barriers on internationalization through much larger samples, and over time. In addition, while the cases in this paper hinted at the role of novel technologies, we see ample room (as already noted above) for additional research into BMSAs, and BMSA recombination barriers, of firms offering or employing ICT and digital technologies, which are also expected to become increasingly important in the context of the energy transition; not least, despite the fact that the firms in the sample are part of the same industry, because they engage in rather different activities. This allowed us to have an overarching view on the developments concerning the energy transition but it also limits comparability. Future studies focusing on specific parts of the value chain, e.g., electricity retailers, could explore whether firms with the same recombination barriers and similar BMSAs manage internationalization differently, and if so how and why. This can give insights into differences of business model configurations across countries. In this context, it would also be worth studying whether all component(s) of the business model can always be adapted or if there is a specific 'core' part in a business model that cannot be altered when entering foreign markets, as it represents the essence of the firm.

Furthermore, while our empirical work used firms active in the electricity sector, in view of its idiosyncrasies it would be worthwhile for scholars to explore how BMSAs and barriers to BMSA recombination unfold in other industries, and in cases beyond our specific setting. They can build on earlier IB work that has already pointed at the variety of energy- and climate-related institutions of relevance to MNEs, across countries and at supranational levels (Kolk \& Pinkse, 2008; Pinkse $\&$ Kolk, 2012). A final interesting avenue might be to advance the conceptualization of BMSA, which we have explained and illustrated in this paper, more prominently in light of other grand challenges, and of leverage burgeoning studies on sustainable business models (Bocken, Short, Rana, \& Evans, 2014; Schaltegger, Lüdeke-Freund \& Hansen, 2016).

\section{ACKNOWLEDGEMENTS}

We would like to thank the firms for their willingness to be interviewed and to share detailed information, as well as the editors, reviewers, and the participants at the AoM JIBS/BJM PDW in Chicago 2018, for their valuable and constructive feedback. We are grateful for the work done by Lena Holzer which enabled the initial submission of this paper. The first author gratefully acknowledges the support from the Horizon 2020 project "inteGRIDy" under Grant agreement 731268.

Open Access This article is licensed under a Creative Commons Attribution 4.0 International License, which permits use, sharing, adaptation, distribution and reproduction in any medium or format, as long as you give appropriate credit to the original author(s) and the source, provide a link to the Creative Commons licence, and indicate if changes were made. The images or other third party material in this article are included in the article's Creative Commons licence, unless indicated otherwise in a credit line to the material. If material is not included in the article's Creative Commons licence and your intended use is not permitted by statutory regulation or exceeds the permitted use, you will need to obtain permission directly from the copyright holder. To view a copy of this licence, visit http:// creativecommons.org/licenses/by/4.0/.

\section{NOTES}

${ }^{1}$ In this paper, we imply that a BMSA is inherent in firms' business models. We base this view on the theorizing of Casadesus-Masanell and Ricart (2010) who argue that the business model is but one set of choices (out of many) which a firm adopts in its strategizing process.

${ }^{2}$ The electricity value chain consists of the following: electricity producers generate electricity from energy sources such as coal or gas in power plants, or from renewable energy sources like wind or solar. The electricity is then transported by the transmission system operator at high voltages by long-distance electricity lines to local neighborhoods where the distribution system operator (DSO) delivers electricity from the grid to the meter at reduced voltage. The electricity is then sold to 
the consumer (industrial, commercial, or residential) by the electricity supplier. As electricity storage is in most cases not cost-effective, electricity supply needs to be matched with demand at all times. We use 'technology provider' as an aggregate term to refer to firms that offer different solutions in the electricity sector, e.g., energy services, energy community solutions, or micro-grids.

${ }^{3}$ Three firms wanted to participate but to remain anonymous for competitive reasons. For these firms, we decided to use generic placeholders describing the primary function of the firm.

\section{REFERENCES}

Alanne, K., \& Saari, A. 2006. Distributed energy generation and sustainable development. Renewable and Sustainable Energy Reviews, 10(6): 539-558.

Alcácer, J., Cantwell, J., \& Piscitello, L. 2016. Internationalization in the information age: A new era for places, firms, and international business networks? Journal of International Business Studies, 47(5): 499-512.

Alotto, P., Guarnieri, M., \& Moro, F. 2014. Redox flow batteries for the storage of renewable energy: A review. Renewable and Sustainable Energy Reviews, 29: 325-335.

Baden-Fuller, C., \& Haefliger, S. 2013. Business models and technological innovation. Long Range Planning, 46(6): 419-426.

Bocken, N. M., Short, S. W., Rana, P., \& Evans, S. 2014. A literature and practice review to develop sustainable business model archetypes. Journal of Cleaner Production, 65: 42-56.

Bohnsack, R., Pinkse, J., \& Kolk, A. 2014. Business models for sustainable technologies: Exploring business model evolution in the case of electric vehicles. Research Policy, 43(2): 284-300.

Bowen, G. 2008. Naturalistic inquiry and the saturation concept: a research note. Qualitative Research, 8(1): 137-152.

Buckley, P. J., Doh, J. P., \& Benischke, M. H. 2017. Towards a renaissance in international business research? Big questions, grand challenges, and the future of IB scholarship. Journal of International Business Studies, 48(9): 1045-1064.

Caprar, D. V., Devinney, T. M., Kirkman, B. L., \& Caligiuri, P. 2015. Conceptualizing and measuring culture in international business and management: from challenges to potential solutions. Journal of International Business Studies, 46: 1011-1027.

Casadesus-Masanell, R., \& Ricart, J. E. 2010. From strategy to business models and onto tactics. Long Range Planning, 43: 105-115.

Cavallo, A., Ghezzi, A., \& Guzmán, B. V. R. 2019. Driving internationalization through business model innovation. Multinational Business Review, 28(2): 201-220.

Chesbrough, H., \& Rosenbloom, R. S. 2002. The role of the business model in capturing value from innovation: Evidence from Xerox Corporation's technology spin-off companies. Industrial and Corporate Change, 11(3): 529-955.

Ciravegna, L., Lopez, L., \& Kundu, S. 2014. Country of origin and network effects on internationalization: A comparative study of SMEs from an emerging and developed economy. Journal of Business Research, 67(5): 916-923.

Ciulli, F., Kolk, A., \& Boe-Lillegraven, S. 2019. Circularity brokers: Digital platform organizations and waste recovery in food supply chains. Journal of Business Ethics. https://doi.org/ 10.1007/s10551-019-04160-5.
${ }^{4}$ During the first revise-and-resubmission (i.e., after the first-round feedback resulting from the presentation at the 2018 Academy of Management Professional Development Workshop), we conducted additional interviews (adding both extra firms to adequately cover the full scope of activities and extra respondents for some of the firms, where allowed) to strengthen the initial findings and to obtain more insights into the themes discovered for the initial submission. We are grateful to the editors and the reviewers for these suggestions.

Corley, K. G., \& Gioia, D. A. 2004. Identity ambiguity and change in the wake of a corporate spin-off. Administrative Science Quarterly, 49(2): 173-208.

Coviello, N., Kano, L., \& Liesch, P. W. 2017. Adapting the Uppsala model to a modern world: Macro-context and microfoundations. Journal of International Business Studies, 48(9): 1151-1164.

Dahlmann, F., Kolk, A., \& Lindeque, J. 2017. Emerging energy geographies: Scaling and spatial divergence in European electricity generation capacity. European Urban and Regional Studies, 24(4): 381-404.

Demil, B., \& Lecocq, X. 2010. Business model evolution: In search of dynamic consistency. Long Range Planning, 43(2/3): 227-246.

Demil, B., Lecocq, X., Ricart, J. E., \& Zott, C. 2015. Introduction to the SEJ special issue on business models: Business models within the domain of strategic entrepreneurship. Strategic Entrepreneurship Journal, 9(1): 1-11.

Denzin, N. K. 2017. Sociological methods: A sourcebook. New York: Routledge.

Doh, J. P. 2015. From the Editor: Why we need phenomenonbased research in international business. Journal of World Business, 50: 609-611.

Dunford, R., Palmer, I., \& Benveniste, J. 2010. Business model replication for early and rapid internationalisation: The ING direct experience. Long Range Planning, 43(5-6): 655-674.

Eisenhardt, K. M. 1989. Building theories from case study research. Academy of Management Review, 14(4): 532-550.

ENTSO-E. 2010. Memo 2009. https://eepublicdownloads.blob. core.windows.net/public-cdn-container/clean-documents/ pre2015/publications/entsoe/Memo/100608_ENTSO-E_ Memo_2009.pdf. Accessed 29 July 2019.

ENTSO-E. 2019. Statistical Factsheet 2018. https:// eepublicdownloads.blob.core.windows.net/public-cdncontainer/clean-documents/Publications/Statistics/Factsheet/ entsoe_sfs2018_web.pdf. Accessed 29 July 2019.

European Commission. 2019. Third Energy Package. https://ec. europa.eu/energy/en/topics/markets-and-consumers/marketlegislation/third-energy-package. Accessed 1 October 2019.

Feuerriegel, S., \& Neumann, D. 2016. Integration scenarios of Demand Response into electricity markets: Load shifting, financial savings and policy implications. Energy Policy, 96: 231-240.

Gaddy, B. E., Sivaram, V., Jones, T. B., \& Wayman, L. 2017. Venture capital and cleantech: The wrong model for energy innovation. Energy Policy, 102: 385-395.

Geels, F., Kern, F., Fuchs, G., Hinderer, N., Kungl, G., Mylan, J., et al. 2016. The enactment of socio-technical transition pathways: A reformulated typology and a comparative 
multi-level analysis of the German and UK low-carbon electricity transitions (1990-2014). Research Policy, 45: 896-913.

Gehman, J., Glaser, V. L., Eisenhardt, K. M., Gioia, D., Langley, A., \& Corley, K. G. 2017. Finding theory-method fit: a comparison of three qualitative approaches to theory building. Journal of Management Inquiry, 27(3): 284-300.

Gioia, D. A., Corley, K. G., \& Hamilton, A. L. 2013. Seeking qualitative rigor in inductive research: Notes on the Gioia methodology. Organizational Research Methods, 16(1): 15-31.

Gioia, D. A., Price, K. N., Hamilton, A. L., \& Thomas, J. B. 2010. Forging an identity: An insider-outsider study of processes involved in the formation of organizational identity. Administrative Science Quarterly, 55(1): 1-46.

Gioia, D. A., Thomas, J. B., Clark, S. M., \& Chittipeddi, K. 1994. Symbolism and strategic change in academia: The dynamics of sensemaking and influence. Organization Science, 5(3): 363-383.

Grøgaard, B., Colman, H. L., \& Stensaker, I. G. 2019. Legitimizing, leveraging, and launching: Developing dynamic capabilities in the MNE. Journal of International Business Studies, https://doi.org/10.1057/s41267-019-00245-5.

Hancher, L., \& Winters, B. M. 2017. The EU Winter Package. Briefing Paper, Allen \& Overy. http://www.allenovery.com/ SiteCollectionDocuments/The\%20EU\%20Winter\% 20Package\%20Briefing\%20paper.pdf. Accessed 10 January 2019.

Hennart, J. F. 2009. Down with MNE-centric theories! Market entry and expansion as the bundling of MNE and local assets. Journal of International Business Studies, 40(9): 1432-1454.

Hollender, L., Zapkau, F. B., \& Schwens, C. 2017. SME foreign market entry mode choice and foreign venture performance: The moderating effect of international experience and product adaptation. International Business Review, 26(2): 250-263.

IEA. 2018. World Energy Outlook 2018. The gold standard of energy analysis. International Energy Agency. https://www. iea.org/weo2018/electricity/. Accessed 15 January 2019.

Knight, J. G., Holdsworth, D. K., \& Mather, D. W. 2007. Country-of-origin and choice of food imports: An in-depth study of European distribution channel gatekeepers. Journal of International Business Studies, 38(1): 107-125.

Knight, G. A., \& Liesch, P. W. 2016. Internationalization: From incremental to born global. Journal of World Business, 51(1): 93-102.

Kolk, A., Lindeque, J., \& Van den Buuse, D. 2014. Regionalization strategies of European Union electric utilities. British Journal of Management, 25: 77-99.

Kolk, A., \& Pinkse, J. 2008. A perspective on multinational enterprises and climate change. Learning from an 'inconvenient truth'? Journal of International Business Studies, 39(8): 1359-1378.

Laufs, K., \& Schwens, C. 2014. Foreign market entry mode choice of small and medium-sized enterprises: A systematic review and future research agenda. International Business Review, 23(6): 1109-1126.

Lee, I. H., \& Marvel, M. R. 2009. The moderating effects of home region orientation on $R \& D$ investment and international SME performance: Lessons from Korea. European Management Journal, 27(5): 316-326.

Love, J. H., Roper, S., \& Zhou, Y. 2016. Experience, age and exporting performance in UK SMEs. International Business Review, 25(4): 806-819.

Lu, J. W., \& Beamish, P. W. 2001. The internationalization and performance of SMEs. Strategic Management Journal, 22(6-7): $565-586$.

Lu, J., Liu, X., Wright, M., \& Filatotchev, I. 2014. International experience and FDI location choices of Chinese firms: the moderating effects of home country government support and host country institutions. Journal of International Business Studies, 45(4): 428-449.
Magretta, J. 2002. Why business models matter. Harvard Business Review, 80: 86-92.

Martin, J. A., \& Eisenhardt, K. M. 2010. Rewiring: cross-businessunit collaborations in multibusiness organizations. Academy of Management Journal, 53(2): 265-301.

Massa, L., Tucci, C. L., \& Afuah, A. 2017. A critical assessment of business model research. Academy of Management Annals, 11(1): 73-104.

McLellan, E., MacQueen, K. M., \& Neidig, J. L. 2003. Beyond the qualitative interview: Data preparation and transcription. Field Methods, 15(1): 63-84.

Morris, M., Schindehutte, M., \& Allen, J. 2005. The entrepreneur's business model: towards a unified perspective. Journal of Business Research, 58: 726-735.

Müller, T., \& Möst, D. 2018. Demand response potential: available when needed? Energy Policy, 115: 181-198.

Nag, R., \& Gioia, D. A. 2012. From common to uncommon knowledge: foundations of firm-specific use of knowledge as a resource. Academy of Management Journal, 55(2): 421-457.

Narula, R. 2014. Exploring the paradox of competence-creating subsidiaries: Balancing bandwidth and dispersion in MNEs. Long Range Planning, 47(1-2): 4-15.

Narula, R., Asmussen, C. G., Chi, T., \& Kundu, S. K. 2019. Applying and advancing internalization theory: The multinational enterprise in the twenty-first century. Journal of International Business Studies, 50(8): 1231-1252.

Narula, R., \& Verbeke, A. 2015. Making internalization theory good for practice: The essence of Alan Rugman's contributions to international business. Journal of World Business, 50(4): 612-622.

Oliver, D. G., Serovich, J. M., \& Mason, T. L. 2005. Constraints and opportunities with interview transcription: Towards reflection in qualitative research. Social Forces, 84(2): 1273-1289.

Osterwalder, A., \& Pigneur, Y. 2010. Business model generation: A handbook for visionaries, game changers, and challengers. Hoboken: John Wiley.

Penrose, E. 1959. The theory of the growth of the firm. Oxford: Oxford University Press.

Pepermans, G. 2019. European energy market liberalization: Experiences and challenges. International Journal of Economic Policy Studies, 13(1): 3-26.

Phene, A., \& Almeida, P. 2008. Innovation in multinational subsidiaries: The role of knowledge assimilation and subsidiary capabilities. Journal of International Business Studies, 39(5): 901-919.

Pinkse, J., \& Kolk, A. 2012. Multinational enterprises and climate change: exploring institutional failures and embeddedness. Journal of International Business Studies, 43(3): 332-341.

Pisani, N., Caldart, A., \& Hopma, J. 2017. SMEs' formation of minority international joint ventures and level of internationalization: The moderating role of a global versus regional focus. European Management Journal, 35(3): 414-424.

Pitelis, C., \& Verbeke, A. 2007. Edith Penrose and the future of the multinational enterprise: New research directions. Management International Review, 47(2): 139-149.

Pollitt, M. G. 2019. The European single market in electricity: an economic assessment. Review of Industrial Organization, 55(1): $63-87$.

Pornpitakpan, C. 1999. The effects of cultural adaptation on business relationships: Americans selling to Japanese and Thais. Journal of International Business Studies, 30(2): 317-337.

Prahalad, C. K., \& Bettis, R. A. 1986. The dominant logic: A new link between diversity and performance. Strategic Management Journal, 7: 485-511.

Rugman, A. M., \& Verbeke, A. 2001. Subsidiary-specific advantages in multinational enterprises. Strategic Management Journal, 22(3): 237-250.

Rugman, A. M., \& Verbeke, A. 2003. Extending the theory of the multinational enterprise: Internalization and strategic 
management perspectives. Journal of International Business Studies, 34(2): 125-137.

Rugman, A. M., \& Verbeke, A. 2004. A perspective on regional and global strategies of multinational enterprises. Journal of International Business Studies, 35: 3-18.

Rugman, A. M., Verbeke, A., \& Nguyen, Q. T. 2011. Fifty years of international business theory and beyond. Management International Review, 51(6): 755-786.

Sabatier, V., Mangematin, V., \& Rousselle, T. 2010. From recipe to dinner: Business model portfolios in the European biopharmaceutical industry. Long Range Planning, 43(2-3): 431-447.

Saldaña, J. 2013. The coding manual for qualitative researchers (2nd ed.). Los Angeles: Sage.

Schaltegger, S., Lüdeke-Freund, F., \& Hansen, E. G. 2016. Business models for sustainability: A co-evolutionary analysis of sustainable entrepreneurship, innovation, and transformation. Organization \& Environment, 29(3): 264-289.

Smaling, A. 1992. Varieties of methodological intersubjectivity the relations with qualitative and quantitative research, with objectivity. International Journal of Methodology, 26(2): 169-180.

Smith, A., \& Raven, R. 2012. What is protective space? Reconsidering niches in transitions to sustainability. Research Policy, 41(6): 1025-1036.

Tallman, S., Luo, Y., \& Buckley, P. J. 2018. Business models in global competition. Global Strategy Journal, 8(4): 517-535.

Teece, D. I. 2010. Business models, business strategy and innovation. Long Range Planning, 43: 172-194.
Teece, D. J. 2018. Business models and dynamic capabilities. Long Range Planning, 51(1): 40-49.

Vahlne, J. E., \& Johanson, J. 2017. From internationalization to evolution: The Uppsala model at 40 years. Journal of International Business Studies, 48(9): 1087-1102.

Van Burg, E., Berends, H., \& Van Raaij, E. M. 2014. Framing and interorganizational knowledge transfer: a process study of collaborative innovation in the aircraft industry. Journal of Management Studies, 51(3): 349-378.

Verbeke, A. 2009. International business strategy. Cambridge: Cambridge University Press.

Verbeke, A., \& Asmussen, C. G. 2016. Global, local, or regional? The locus of MNE strategies. Journal of Management Studies, 53(6): 1051-1075.

Verbeke, A., Coeurderoy, R., \& Matt, T. 2018. The future of international business research on corporate globalization that never was.... Journal of International Business Studies, 49(9): 1101-1112.

Verbeke, A., \& Kano, L. 2016. An internalization theory perspective on the global and regional strategies of multinational enterprises. Journal of World Business, 51(1): 83-92.

Yin, R. K. 1994. Discovering the future of the case study method in evaluation research. Evaluation Practice, 15(3): 283-290.

Zott, C., \& Amit, R. 2010. Business model design: An activity system perspective. Long Range Planning, 43(2-3): 216-226.

\section{APPENDIX: KEY FOR COUNTRY ABBREVIATIONS INCLUDING GDP PER CAPITA}

\begin{tabular}{|c|c|c|c|}
\hline Key country codes & Country & Number of firms & $\begin{array}{l}\text { GDP per capita in } \\
\text { International Dollars in } 2020\end{array}$ \\
\hline FR & France & 1 & 48,640 \\
\hline UK & United Kingdom & 1 & 48,168 \\
\hline ES & Spain & 2 & 43,007 \\
\hline CY & Cyprus & 1 & 42,956 \\
\hline IT & Italy & 2 & 41,582 \\
\hline PT & Portugal & 2 & 34,935 \\
\hline GR & Greece & 3 & 31,616 \\
\hline RO & Romania & 2 & 29,554 \\
\hline Average of sample & & & 40,057 \\
\hline $\begin{array}{l}\text { Average of sample weighted } \\
\text { according to number of firms per country }\end{array}$ & & & 38,054 \\
\hline Average in the European Union & & & 41,749 \\
\hline Average World & & & 23,112 \\
\hline
\end{tabular}

Source: IMF, https://www.imf.org/external/pubs/ft/weo/2019/02/weodata/index.aspx. Accessed 24 July 2020. 


\section{ABOUT THE AUTHORS}

René Bohnsack is Associate Professor at Católica Lisbon School of Business \& Economics. His expertise is business model innovation and strategy, especially in relation to sustainable technologies. He founded the Business Model Design Lab as part of bringing research insights to practice; his business model innovation platform www. venturely.io was recently awarded the best ICT tool 2019 by Wharton and QS.

Francesca Ciulli will join Tilburg University's Department of Organization Studies on 1 November 2020, after prior appointments at Radboud University as assistant professor and the University of Amsterdam as postdoc on a four-year project funded by the Netherlands Organization for Scientific Research. Her research focuses on business and novel digital technologies, in relation to sustainability, sustainable development, and grand challenges.
Ans Kolk is full professor at the University of Amsterdam, Amsterdam Business School, the Netherlands. Her areas of expertise are in corporate social responsibility, sustainable development, and sustainability, especially in IB and GVCs. One stream of research, on which she has also published extensively since the late 1990s, relates to energy and climate change. For more information, see http://www.anskolk.eu

(c) (i) $(-)$ This work is licensed under a Creative Com NC No Comms Attribution-NonCommercial-NoDerivs 3.0 Unported License. The images or other third party material in this article are included in the article's Creative Commons license, unless indicated otherwise in the credit line; if the material is not included under the Creative Commons license, users will need to obtain permission from the license holder to reproduce the material. To view a copy of this license, visit http:// creativecommons. org/licenses/by-nc-nd/3.0/

Publisher's Note Springer Nature remains neutral with regard to jurisdictional claims in published maps and institutional affiliations.

Accepted by Alain Verbeke, Editor-in-Chief, 13 August 2020. This article has been with the authors for two revisions. 